UNIVERSITY

OF DEBRECEN

FACUlty OF

HeALth

NYíREGYHÁZA

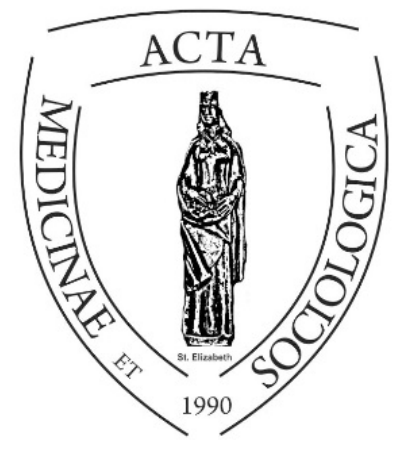

ACTA

MedSoc

VOLUME 7.

2016

\title{
A „Nyíregyháza Ifjúsága 2015” kutatás módszertana
}

\section{The research method of "Youth of Nyíregyháza 2015" Research}

\author{
Huszti Éva, Takács Péter, Hüse Lajos
}

\begin{abstract}
This study shows the background, sample, research method and the aspects of database of the "Youth of Nyíregyháza 2015".

Keywords: research method, questionnaire, database

DOI: $10.19055 /$ ams.2016.7/20-21/11

\section{Absztrakt}

A tanulmány a "Nyíregyháza Ifjúsága 2015" kutatás létrejöttének hátterét mutatja be. Kitér továbbá a vizsgálati mintára és a kutatás módszertanára, valamint bemutatja az adatbázis jellemzőit.
\end{abstract}

Kulcsszavak: kutatási módszertan, kérdőív, adatbázis 
A „Nyíregyháza Ifjúsága 2015” címü kutatásra az év júniusa és szeptembere között került sor a HumanNet Alapítvány és a Debreceni Egyetem Egészségügyi Kar együttmúködésében, Nyíregyháza Megyei Jogú Város Polgármesteri Hivatalának támogatásával. A felmérés két korcsoportot vizsgált: a 15-18 illetve a 19-29 évesek körét. A két korosztályból összesen 733 fö töltötte ki a kérdőívet. A vizsgált dimenziók mindkét korosztály esetben hasonlóak voltak és követték a „Magyar Ifjúság 2012” kutatás során alkalmazott kérdőívek szerkezetét és tematikáját, így az adatok összehasonlíthatók az országos és régiós adatokkal is.

A kutatásban a HumanNet Alapítvány munkatársain és a Debreceni Egyetem Egészségügyi Kar oktatóin, munkatársain kívül nagy számban vettek részt a Kar hallgatói.

\section{A kutatás háttere}

A Nyíregyházán immár rendszeresen megvalósuló életminőség-kutatás sorozat (2008, 2010, 2012 és 2015) bebizonyította, hogy nem csupán arra alkalmas, hogy tudományos minőségü adatokra alapozva tudományos publikációk szülessenek a tudomány elefántcsont-tornyában, hanem kifejezetten jól használhatóak a város szociális és egészségügyi koncepciójának megalapozására, monitorozására és korrigálásra. Az életminőség-kutatás évek óta megalapozott tervezési eszközként szolgál a városi szociálpolitika számára, és alkalmat ad a beavatkozási eszközök kidolgozására, finomítására.

Az életminőség-kutatás során feltárt adatok képet adnak az egyes társadalmi csoportokról is, ugyanakkor nyilvánvaló, hogy a fontosabb szerepet játszó, vagy speciális helyzetủ rétegek esetében további célzott kutatások is szükségszerüek. A kitünő tapasztalatok arra irányították rá Nyíregyháza vezetésének figyelmét, hogy a készülő ifjúsági koncepció előkészítési munkálatai során érdemes megvalósítani egy olyan, ifjúságra fókuszáló kutatást, amely hasonló szerepet tölthetne be a tervezési folyamatban, mint a már említett életminőség-kutatás sorozata. Ez a határozott szándék indította el a „Nyíregyháza Ifjúsága 2015” kutatást, melynek módszertana követi az országos nagymintás ifjúságkutatások fontosabb módszertani és tematikai jellemzőit.

\section{A kérdőív jellemzői}

Ahogy fentebb utaltunk rá, a „Nyíregyháza Ifjúsága 2015” kutatás kérdőívének tematikája és szerkezete követte a „Magyar Ifjúság 2012” kutatás során alkalmazott kérdőívek jellemzőit. Mivel a nyíregyházi adatfelvétel során, eltérően az országos adatgyüjtéstöl, papír alapú kérdőíves lekérdezést folytattunk, több helyen módosítanunk, egyszerüsítenünk kellett az országos kutatásban használt kérdőívet. Az általános módosításokon túl, a fiatalabb korcsoportban használt, nyíregyházi 
kérdőív szerkezete is eltért minimálisan az idősebbekétől, hiszen voltak olyan kérdések és kérdéscsoportok, melyek a középiskolás korosztály esetében nem voltak relevánsak. Emiatt a kérdésblokkok sorrendje némiképp eltérő volt - lásd az 1. táblázatot.

1. táblázat. A két korcsoport kérdöiv szerkezete

\begin{tabular}{|l|l|}
\hline \multicolumn{1}{|c|}{$15-18$ évesek $(\mathrm{n}=240)$} & \multicolumn{1}{c|}{$19-29$ évesek $(\mathrm{n}=493)$} \\
\hline Általános adatok & Általános adatok \\
\hline Oktatás & Család, gyermekvállalás \\
\hline Munkaerö-piaci tapasztalat & Oktatás \\
\hline Külföldi munka és tanulás & Munkaerö-piac \\
\hline Közéleti kérdések & Külföldi munka és tanulás \\
\hline Család, gyermekvállalás & Közéleti kérdések \\
\hline Média & Média \\
\hline Sport, szabadidő & Sport, szabadidő \\
\hline Rizikómagatartás & Rizikómagatartás \\
\hline Lakáshelyzet, életkörülmények & Lakáshelyzet, életkörülmények \\
\hline Közösségi élet & Közösségi élet \\
\hline Generációk együttmüködése & Generációk együttmüködése \\
\hline Kérdések a kérdezöhöz & Kérdések a kérdezöhöz \\
\hline
\end{tabular}

A 19-29 évesek teljes kérdőíve megtalálható a tanulmány mellékletében. Terjedelmi okokból a 15-18 évesek tartalmilag szükebb kérdőívét nem közöljük.

\section{A 15-18 éves korosztály almintája}

A korcsoport esetében a nyíregyházi középiskolákba járó diákok adták a vizsgálati populációt. Eredetileg 300 olyan fiatal megkérdezése volt a cél, akik a város valamelyik középiskolájában tanulnak. A mintavétel több lépcsőből állt: először az iskolákból vettünk mintát az iskola típusától függően (figyelembe véve a városban lévő különböző típusú középiskolák arányait), így a 2. táblázatban felsorolt iskolák kerültek a mintába: 


\section{2. táblázat. A mintába került középiskolák}

\begin{tabular}{|c|c|c|}
\hline Gimnáziumok & $\begin{array}{l}\text { Zrínyi Ilona Gimnázium és Kollégium; } \\
\text { Eötvös József Gyakorló Általános Iskola és } \\
\text { Gimnázium; } \\
\text { Evangélikus Kossuth Lajos Gimnázium; } \\
\text { Szent Imre Katolikus Gimnázium; } \\
\text { Krúdy Gyula Gimnázium }\end{array}$ & $\begin{array}{l}\text { iskolánként } 24 \text { fö; } \\
\text { vegyesen az } \\
\text { évfolyamokról; } \\
\text { tervezett összesen } \\
120 \text { fó gimnazista }\end{array}$ \\
\hline Szakközépiskolák & $\begin{array}{l}\text { Zay Anna } \\
\text { Egészségügyi, Informatikai } \\
\text { Szakközépiskola és Kollégium; } \\
\text { Széchenyi István Közgazdasági, } \\
\text { Informatikai Szakközépiskola és } \\
\text { Kollégium; } \\
\text { Müvészeti Szakközépiskola }\end{array}$ & $\begin{array}{l}\text { iskolánként } 20 \text { fö; } \\
\text { vegyesen az } \\
\text { évfolyamokról; } \\
\text { tervezett összesen } 60 \\
\text { szakközépiskolás. }\end{array}$ \\
\hline Szakiskolák & $\begin{array}{l}\text { Lippai János Mezőgazdasági Szakképző } \\
\text { Iskola; } \\
\text { Bencs László Szakiskola és Általános } \\
\text { Iskola; } \\
\text { Sipkay Kereskedelmi, } \\
\text { Vendéglátóipari, } \\
\text { Középiskola, Szakiskola és Kollégium; } \\
\text { Wesselényi Miklós Középiskola, } \\
\text { Szakiskola és Kollégium; } \\
\text { Inczédy György Középiskola, Szakiskola } \\
\text { és Kollégium; Án } \\
\text { Bárczi Gusztáv Általános Iskola, } \\
\text { Készségfejlesztő Speciális Szakiskola, } \\
\text { Kollégium és Egységes Gyógypedagógiai } \\
\text { Módszertani Intézmény }\end{array}$ & $\begin{array}{l}\text { iskolánként } 24 \text { fö; } \\
\text { vegyesen az } \\
\text { évfolyamokról; } \\
\text { tervezett összesen } \\
120 \text { fó szakiskolás }\end{array}$ \\
\hline
\end{tabular}

A következö mintavételi lépés az iskolák közvetlen megkeresése volt. A mintába került iskolák vezetőit arra kértük, hogy az összes évfolyamot reprezentálva válasszanak ki megadott számú diákot a kérdezésre, akik önként vállalják a kutatásban való részvételt. A megkérdezett diákok esetében minden esetben írásos szülői beleegyezéssel történt az adatfelvétel.

Az eljárás során sok kollégista is bekerült a mintába, hiszen a kérdezett diákok esetében nem volt kikötés, hogy nyíregyháziak legyenek - így a minta ezen darabja nem csak nyíregyházi lakosú, hanem a Nyíregyházán tanuló diákokra vonatkoztatható.

A tényleges adatfelvételt a Debreceni Egyetem Egészségügyi Kar hallgatói végezték, az elöre rögzített időpontokban felkeresve az iskola által kijelölt diákokat. 
Az adatfelvétel 2015 szeptemberében zajlott. A kérdezőbiztosok az adatfelvétel előtt felkészítésen vettek részt. Mivel arra nem volt lehetőség, hogy minden középiskolással külön-külön időpontban készüljön kérdőíves adatfelvétel, a hallgatók 3-4 fős csoportokban dolgoztak a diákokkal. Ez alól kivétel volt az kérdöív érzékeny, személyes jellegü adatokat tartalmazó része, az „önkitöltősre” szerkesztett „,rizikómagatartás” blokk. Ezt minden diák egyénileg töltötte ki. A válaszadás önkéntes volt, a kérdezőbiztosok a válaszadókat biztosították arról, hogy válaszaik a továbbiakban anonim módon kerülnek felhasználásra. Ezt minden esetben így is történt.

A középiskolákban a tervezett 300 föből végül 240 főt értek el a kérdezőbiztosok. Ez 80 százalékos lekérdezési arányt jelent. Sok esetben hiányzások, szülői engedély elmaradása („,otthonfelejtése”) és más tényezők akadályozták meg a tervezett keret elérését.

A megkérdezettek $53 \%$-a lány, $47 \%$-a fiú volt. Az iskolatípusok megoszlása: 40 \%a gimnazista, 20 \%-a jár szakközépiskolába és $40 \%$-uk szakiskolás volt. A mintában további súlyozást nem végeztünk.

\section{A 19-29 évesek almintája}

A mintavétel alapját a Közigazgatási és Elektronikus Közszolgáltatások Központi Hivatala által szolgáltatott címlista szolgáltatta. A mintába kiválasztott fiatalokat a korábbi gyakorlathoz hasonlóan (Nyíregyháza Életminősége 2008, 2010, 2012, 2015) a város polgármestere és a kutatásvezető által aláírt lakossági levélben tájékoztattuk a kérdezésről, annak céljáról és a kérdezés várható idejéről.

A mintavétel célja 600 olyan fiatal megkérdezése volt, akik állandó bejelentett lakcímmel rendelkeznek Nyíregyházán és a kijelölt korcsoportba tartoznak. Ezen kívül 100 olyan fiatalt is meg akartunk kérdezni, akik nem nyíregyházi lakosok, de itt folytatják felsőfokú tanulmányaikat.

A gondos előkészítő munka ellenére a kérdezőbiztosok rengeteg nehézséggel találkoztak a mintában szereplő címeket felkeresve. Az elsődleges címen megjelölt források közül sok válaszadót nem lehetett elérni. Ezen esetekben pótcímet kellett alkalmazni. Az adatfelvételt leggyakrabban az akadályozta meg, hogy az adott címen bejelentett, a kutatásba bevonni szándékozott személy már nem ott lakott életvitelszerüen. A kérdezőbiztosok elmondásai alapján a fentieken kívül legnagyobb gondot a válaszmegtagadás és a rossz elérés jelentette. Az adatfelvételt végzők sokszor nem találták otthon a fiatalokat, sokan elköltöztek vagy egyszerüen megtagadták a válaszadást az újbóli felkereséskor. A hozzátartozók sem segítették a 
kérdezőbiztosok munkáját - az otthontartózkodó szülők, testvérek vagy át sem adták a kérdezőbiztos üzenetét a felkeresésről vagy a megkérdezett döntött úgy, hogy nem vesz részt a kutatásban.

Az eredetileg 2015 nyarára - pontosabban 2015 augusztusára - tervezett kérdezés minimálisan kitolódott és még szeptemberben is zajlott (pótcímek, pót-pótcímek).

Az adatfelvétel során tapasztalható, a tolerálhatónál nagyobb arányú sikertelen felkeresések miatt szeptember végén adatfelvételi módszert váltottunk és a „hólabda módszerre" áttérve folytatták az adatfelvételt a kérdezőbiztosok. Az így elért minta nagyobb merítést jelent a vizsgálat során, ugyanakkor nem reprezentatív a vizsgált célcsoport tekintetében.

Összesen 493 sikeres kérdezés zajlott a korcsoportban, mely tartalmazza az elért felsőfokú tanulmányaikat végzőket is. A megkérdezettek $53 \%$-a nő, 47 \%-a férfi volt.

\section{További megfontolások}

A mintavétel tanúságai összefoglalva más, jövőbeni adatfelvételekre vonatkoztatva a következők:

- Az eljárás során célszerübb pontosabb, részletesebb felvilágosítást adni az adatfelvétel gyakorlati lépéseiről a középiskolák vezetőinek, az osztályfönököknek és az érintett diákoknak, hogy jobban fel tudjanak készülni a diákok kérdezőbiztossal történő és nem csoportos, önkitöltős kérdőív lekérdezésére.

- Az idősebb korcsoport esetében igen nagy probléma volt az, hogy a címnyilvántartásban megadott személy más városban tanult, vagy dolgozott, de még nyíregyházi állandó lakosként volt regisztrálva.

\section{Az elemzések közvetlen előkészítése és megvalósulása}

Az adatfelvétel után a Debreceni Egyetem Egészségügyi Kar hallgatói statisztikai gyakorlat keretében vállalkoztak a kérdőívek rögzítésére. Az adatbevitel Excelben történt. A két korcsoport adatai külön kerültek rögzítésre.

A nagyszámú kérdés (699) és kérdőív nem tette lehetővé a közvetlen bevitelt, adattranszformációs módszereket kellett alkalmazni a teljes adattábla kialakítására. Ehhez az OpenOffice Calc programcsomagjának lehetőségeit is használni kellett. Az elkészült korcsoportos adattáblák kerültek egy újabb transzformációval az SPSS statisztikai rendszerbe (IBM SPSS V22.00), ahol még további összevonások, segédváltozók képzése és a tényleges statisztikai adatfeldolgozás zajlott. A 
statisztikai vizsgálatokat és elemzést végző kollégák három állományt kaptak kézhez: a két korcsoportra vonatkozó adatokat külön és egy összevont adatállományt, amely az 1. táblázatban szereplő közös kérdésblokkokat tartalmazta.

$\mathrm{Az}$ elemzések tématerületenként egyéni, vagy csoportos munka keretében történtek. Sikerült elérni, hogy a tartalmilag és formailag már majdnem lezárt dolgozatokat a tanulmányok készítői egymás között kicserélhessék, megismerhessék a párhuzamosan folyó munkákat. Ez lehetővé tette, hogy még a kötet megjelenése előtt hivatkozni tudjanak azokra a gondolatokra, amelyek szerzőtársaiktól eredtek. Ennek közvetlen nyoma az irodalomjegyzékekben látható, közvetetten pedig abban, hogy a kutatócsoport egy egységesebb képpel tudott olvasói és a szociálpolitikai döntéshozók elé lépni.

A kötet statisztikai elemzései legjellemzőbben leíró statisztikai elemeket (eloszlási arányokra, középértékre, szóródásra vonatkozó számítások és ábrák) tartalmaznak. Ezen kívül kétmintás paraméteres és nem-paraméteres próbák (tpróba, khí-négyzet próba, Fieher-féle egzakt teszt, Mann-Whitney teszt) elvégzése adott eredményeket a vizsgálatokban. Az összetettebb vizsgálatokban bináris logisztikus regresszió és faktoranalízis is szerepel. A statisztikai próbáknál az általánosan alkalmazott 5 százalékos hibahatárt tekintettük mérvadónak.

\section{Köszönetnyilvánítás}

Itt köszönjük meg kutatótársaink nevében is Dr. Ulrich Attila Nyíregyháza Megyei Jogú Város alpolgármesterének és Dr. Krizsai Anita, a Nyíregyháza Megyei Jogú Város Önkormányzatának Szociális és Köznevelési Osztály vezetőjének segítő támogatását a „Nyíregyháza Ifjúsága 2015” kutatás megalapozásában és egy régóta dédelgetett terv valóra váltásában.

A „Nyíregyháza Ifjúsága 2015” felmérés előkészítésében, megvalósításában köszönettel tartozunk még:

- a kutatásban részt vett középiskolák vezetésének, tanárainak segítőkész támogatásukért;

- Sarkadi Erzsébet Annának a kérdőívek szerkesztéséért, sokszorosításáért;

- a Debreceni Egyetem Egészségügyi Kar hallgatóinak, akik mind kérdezőbiztosként, mind adatrögzítőként segítették a vizsgálat megvalósulását, valamint

- az adatfelvételben részt vett minden kérdezőbiztosnak fáradságos és lelkiismeretes munkájáért. 


\section{A szerzők}

Huszti Éva PhD. szociológus, föiskolai docens

Debreceni Egyetem Egészségügyi Kar, 4400 Nyíregyháza Sóstói u. 2-4.

Takács Péter PhD. statisztikus, föiskolai docens

Debreceni Egyetem Egészségügyi Kar, 4400 Nyíregyháza Sóstói u. 2-4.

Hüse Lajos PhD. szociológus, föiskolai docens

Debreceni Egyetem Egészségügyi Kar, 4400 Nyíregyháza, Sóstói u. 2-4. 
$\Gamma$

\begin{tabular}{|c|c|c|}
\hline EvaSys & Nyíregyháza ifjúsága 2015 & 巳 Electric Paper \\
\hline \hline Debreceni Egyetem & A KÉRDÖÍV BIZALMASAN KEZELENDÖ! \\
Egészségügyi Kar & A VÁLASZADÁS ÖNKĖNTES! & \\
& CSAK 19-29 ÉVESEKTÖL KÉRDEZHETŐ! & DP \\
\hline
\end{tabular}

Válasz megjelölése: $\square \bigotimes \square \square \square$ Kérem, használjon tollat vagy vékony hegyủ filcet. Az ürlap automatikus feldolgozásra kerül.

Javitás: $\quad \square \square \square \bigotimes \square$ Az optimális beolvasási eredmények érdekében kérem, kövesse a bemutatott példákat.

1.

1.1 A kérdőív sorszáma:

1.2 Főcím vagy pótcím:

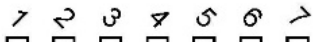

1.3 Meghiúsulás oka:

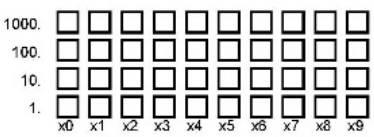

!!KÉRDEZÕ: Amennyiben az előzō kérdésnél a 7. és 8. választ jelölte meg, akkor kell az alábbi

$>30 \times 2>\infty \theta^{\prime}>$ kérdést feltenni!!

$1.4 \mathrm{Ha}$ a kérdezendő más településre, vagy külföldre költözött, elsősorban miért költözött el?
$\square$ munka
$\square$ tanulás
$\square$ NT

$\square \mathrm{NV}$

\section{CSALÁD, GYERMEKVÁLLALÁS}

2.1 A válaszadó neme:

2.2 Születési éve:

2.3 Születési hónapja: $\square$ fiú/férfi

$\square$ lány/nő

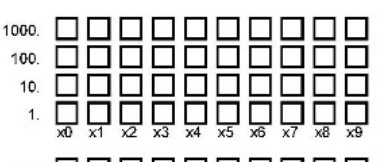

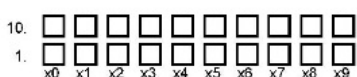

2.4 Mi az Ön jelenlegi családi állapota? (nötlen, hajadon; elvált; özvegy; esetén ugrás 2.6-ra)
$\square$ hazas
$\square$ elvált
$\square$ (bejegyzett) élettársi kapcsolat
$\square$ özvegy
nötlen, hajadon
NT

2.5 Együtt él Ön a házastársával/élettársával?
$\square$ igv
$\square$ nem
$\square$ NT

2.6 Van Önnek élettársa, partnere, akivel együtt élnek?
$\square$ van
$\square$ nincs
$\square$ NT

2.7 Van-e Önnek jelenleg párkapcsolata (barátnő, barát)?
$\square$ van
$\square$ nincs
$\square$ NT

2.8 Volt-e már Önnek korábban párkapcsolata (barátnő, barát)?

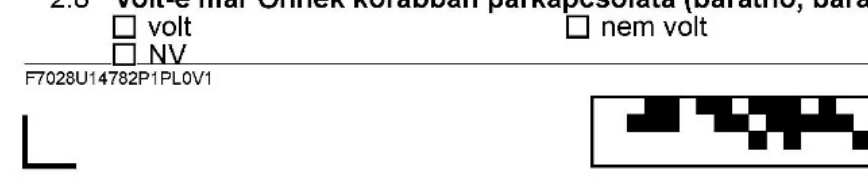


EvaSys $\quad$ Nyíregyháza ifjúsága 2015

2. CSALÁD, GYERMEKVÁLLALÁS [Folytatás]

2.9 Élt-e már Ön valaha házasság nélkül élettársi kapcsolatban? (együtt éltek, együtt laktak)

(HA HÁZAS: AZ IS SZÁMIT, HAA HÁZASSÁG ELOTTT MÁR EGYÜTT ÉLTEK.)

igen

$\square$ nem

$\square \mathrm{NT}$

NV

2.10 Hány éves volt Ön az első élettársi kapcsolata létesítésekor?

2.11 Hány éves volt Ön az elsõ élettársi kapcsolata létesítésekor?

nem tudom

(NT)

2.12 Hány éves volt, amikor házasságot kötött? (Ha többször is volt: az elsó számít)

2.13 Hány éves volt, amikor házasságot kötött?
$\square$ nem volt még házas
$\square$ nem tudom (NT)

2.14 Hány gyermeke (vér szerinti és/vagy nevelt) van Önnek összesen?

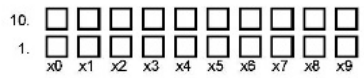

nem válaszolt (NV)

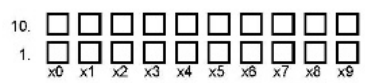

2.15 Hány gyermeke (vér szerinti és/vagy nevelt) van Önnek összesen?

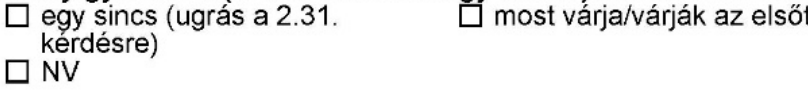

2.16 Hány éves volt Ön, amikor az első gyermeke megszületett?

2.17 Hány éves volt Ön, amikor az elsô gyermeke megszületett?

\section{nem tudom}

(NT)

(NV)

Miért nem fiatalabb korában vállalta az első gyermeket? NYITOTT KÉRDÉS!

2.18 anyagi, jövedelmi okok

2.19 lakáskörülmények

2.20 munkája miatt

2.21 karrierépités miatt

2.22 továbbtanulás miatt

2.23 partner hiánya

2.24 gyerekneveléssel járó többletfeladatok

2.25 egészségügyi okokból

2.26 családi okokból

2.27 egyszerüen nem akar(t)

2.28 túl fiatal lenne/lett volna hozzá

2.29 partnere nem akar/nem akart

2.30 Egyéb, éspedig:

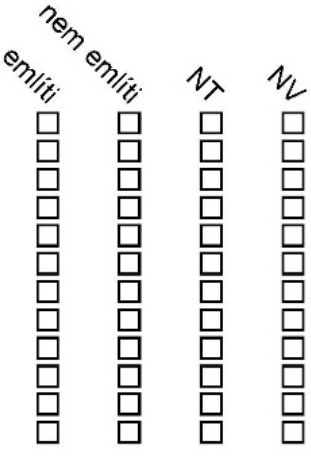

2.31 Tervezi-e, hogy a KÖVETKEZŌ 3 ÉVEN BELÜL (újabb) gyermeket vállal?

$\square$ mindenképpen

$\square$ inkább igen

$\square$ inkább nem

semmiképpen

nem lehet (több) gyermeke

$\square$ NT 
EvaSys $\quad$ Nyíregyháza ifjúsága 2015

2. CSALÁD, GYERMEKVÁLLALÁS [Folytatás]

2.32 Összesen hány gyereket szeretne? (Ha van már gyermeke, vagy épp gyermeket vár: hány gyereket szeretne MEG, a meglévókön és az esetleg jelenleg várt gyermeken kivüil)? 2.33 Összesen hány gyereket szeretne? (Ha
van már gyermeke, vagy épp gyermeket

vár: hány gyereket szeretne MEG, a

meglévökön és az esetleg jelenleg várt gyermeken kívül)?

Mi az oka annak, hogy Ön nem tervez (több) gyereket? (annál többet, mint amit mondott) NYITOTT KÉRDES!

2.34 anyagi, jövedelmi okok

2.35 lakáskörülmények

2.36 munkája miatt

2.37 karrierépités miatt

2.38 partner hiánya

2.39 gyerekneveléssel járó többletfeladatok

2.40 egészségügyi okokból

2.41 családi okokból

2.42 egyszerüen nem akar

2.43 túl idősen szülte az első gyermekét

2.44 a jelenlegi gyerekszám elegendő

2.45 mert már túl idősek/lesznek hozzá

2.46 partnere nem akar

2.47 Egyéb, éspedig:

$\square$ NT

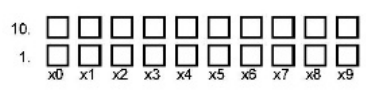

$\square N V$ 


\begin{tabular}{|c|c|c|c|c|c|}
\hline \multicolumn{6}{|c|}{ Nyíregyháza ifjúsága 2015} \\
\hline \multicolumn{6}{|c|}{ 2. CSALÁD, GYERMEKVÁLLALÁS [Folytatás] } \\
\hline $\begin{array}{l}2.57 \text { part } \\
2.58 \text { gyer } \\
2.59 \text { egé } \\
2.60 \text { csal } \\
2.61 \text { egys } \\
2.62 \text { túl fi } \\
2.63 \text { part }\end{array}$ & tok & $\begin{array}{l}\square \\
\square \\
\square \\
\square \\
\square \\
\square\end{array}$ & 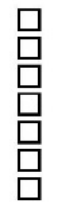 & $\begin{array}{l}\square \\
\square \\
\square \\
\square \\
\square \\
\square \\
\square\end{array}$ & $\begin{array}{l}\square \\
\square \\
\square \\
\square \\
\square \\
\square\end{array}$ \\
\hline
\end{tabular}

2.64 Egyéb, éspedig:

\section{IKÉRDEZŐ: MINDENKITŐL KÉRDEZNI!}

Ha valamikor élete során olyan helyzetbe kerülne, hogy nem lehet közös gyermekük párjával, megpróbálkozna-e a következö lehetőségekkel?

2.65 meddőség elleni kezelés

2.66 lombikbébiprogram/mesterséges megtermékenyítés

2.67 béranyaság

2.68 örökbefogadás

2.69 másik/alkalmas partnert keresne

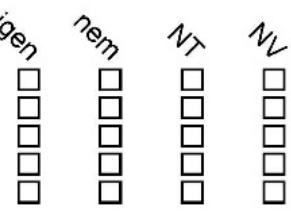

A jelenlegi (legutóbbi) párkapcsolatában mekkora szerepet játszik, mennyire fontos...

Kérem, hogy az iskolában megszokott módon, egy egytöl ötig terjedó skála segítségével válaszoljon ( 1 = egyáltalán nem fontos...5= teljes mértékben fontos)

2.70 hasonló gondolkodásmód

2.71 jó anyagi helyzet

2.72 bensöséges érzelmi kapcsolat (szerelem)

2.73 család véleménye

2.74 barátok véleménye

2.75 szexualitás

2.76 vonzó külső

2.77 megbizhatóság

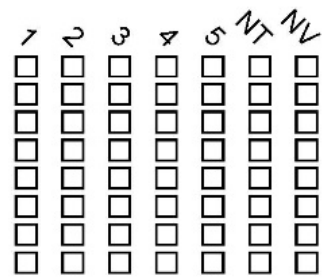

2.78 Ha Ön jelenleg nem házas, szeretne-e házasságban élni? (Akár a közeli, akár a távoli jövőben.)

$\square$ biztosan nem

$\square$ biztosan igen

$\square$ inkább nem

NT

$\square$ inkább igen

Mennyire vonatkoztathatók Önre egyenként az alábbiak?

Kérem, hogy az iskolában megszokott módon, egy egytöl ötig terjedő skála segítségével válaszoljon. ( $1=$ egyáltalán nem.....5= teljes mértékben)

Azért kötött/kötne házasságot, mert...

2.79 a környezete (a társadalom elvárja)

2.80 ez vallási elöírás

2.81 jobb anyagi helyzetet teremt

2.82 így a szülóktől független, önálló életet élhet

2.83 a gyerekek számára ez a legjobb

2.84 erősebb párkapcsolati köteléket jelent

2.85 az együttélés legjobb/legtermészetesebb módja

2.86 bizonyos szolgáltatásokhoz (pl. hitel, bölcsöde) így könnyebb hozzájutni

2.87 kiegyensúlyozottabb szexuális életet jelent

2.88 pozitiv mintákat látott, hallott

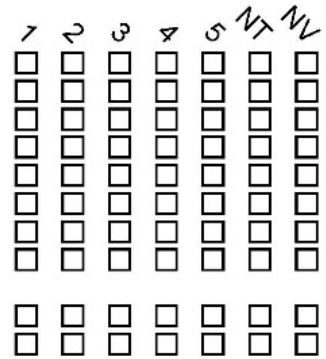


\begin{tabular}{l|c|c|} 
EvaSys & Nyíregyháza ifjúsága 2015 & Electric Paper \\
\hline
\end{tabular}

2. CSALÁD, GYERMEKVÁLLALÁS [Folytatás]

Mi tartotta/tartja vissza a házasságkötéstől? Mennyire vonatkoztathatók Önre egyenként az alábbiak?

Azért nem kötött/kötne házasságot, mert...

2.89 a környezete (a társadalom) nem várja el

2.90 túl sok kötöttséget jelent

2.91 elöbb be akarja fejezni a tanulmányait

2.92 még túl fiatal ehhez

2.93 még nem biztos, hogy megtalálta az igazit

2.94 nem akar gyerekeket

2.95 hiányoznak hozzá az anyagi feltételek

2.96 nem ért egyet a házasság intézményével

2.97 negativ élményei vannak környezetéböl

2.98 élettársa/párja/partnere nem akar házasságot kötni

2.99 családja ellenzi

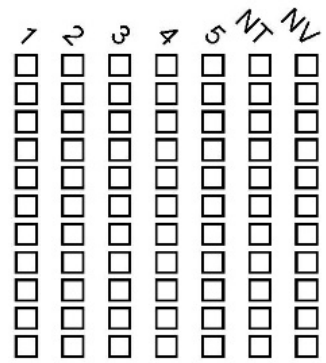

Véleménye szerint mennyire fontos a házasságkötéshez...?

2.100 az anyagi stabilitás

2.101a megfelelö lakásviszonyok

2.102a szülök beleegyezése/jóváhagyása

2.103a tanulmányok befejezése

2.104a biztos munkahely

2.105a kölcsönös tisztelet/megbecsülés

$2.106 a$ hasonló gondolkodás

2.107a szerelem

2.108a barátok véleménye

2.109a jó szexuális kapcsolat

2.110a megbízhatóság

2.111a gyermekvállalàsi szándék

2.112Hol helyezné el önmagát a következő skálán aszerint, hogy minek van nagyobb szerepe az életében?

( $1=$ családi élet, magán élet....5=hivatás, munka, tanulás)

2.113És melyik álításhoz érzi inkább közelebb állónak magát?

( $1=A z$ ember sajnos választásra kényszerül, a

gyerekvállalás és a munkavállalás gyakran már-már

kizáriák egymást......5=Aki igazán akarja, azt a

munkája nem akadályozza meg a gyerek-vállalásban

sem gyerek a munkavállalásban.)

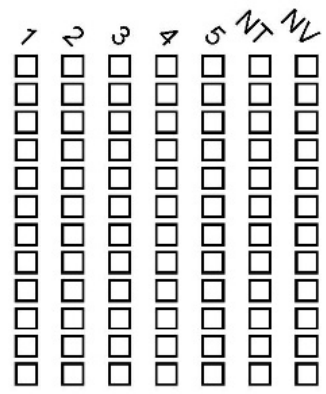

$>20 \times v^{2} V_{L}$

$\square \square \square \square \square \square \square$

$>538 s v_{\lambda} v_{2}$

$\square \stackrel{\square}{\square} \square \square \square$ 
\begin{tabular}{l|c|c|} 
EvaSys & Nyíregyháza ifjúsága 2015 & Electric Paper \\
\hline
\end{tabular}

2. CSALÁD, GYERMEKVÁLLALÁS [Folytatás]

Életeseményeket fogok felsorolni. Kérem, mondja meg, hogy megtörténtek-e már ezek Önnel? Megtörtént-e?

2.114elköltözni a szülői házból, szülöktől függetlenül élni

$2.115 a z$ első szakmai végzettséget megszerezni

2.116elöször önálló, saját lakásba költözni

2.117befejezni tanulmányait

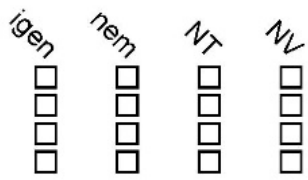

Hány éves korában történt? Hány éves korában fog történni? 2.118elköltözni a szülöi házból, szülőktöl függetlenül élni

2.119

2.120 az első szakmai végzettséget megszerezni

2.121

2.122elöször önálló, saját lakásba költözni

2.123

2.124befejezni a tanulmányait

2.125

2.126Vállalná-e, hogy a gyermekét egyedül nevelje?
$\square$ biztosan nem
inkább nem

$\square$ biztosan igen

$\square$ NT $\square$ NT

$\square$ NT

$\square \mathrm{NT}$

$\square$ NT

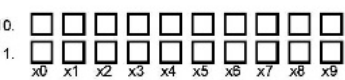

$\square \mathrm{NV}$

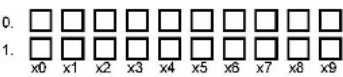

$\square \mathrm{NV}$

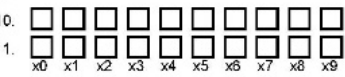

$\square \mathrm{NV}$

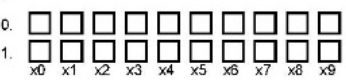

\section{OKTATÁS}

3.1 Mi az Ön legmagasabb, befejezett iskolai végzettsége?

$\square$ nem járt iskolába $\square$ kevesebb, mint 8 oszt

$\square$ szakmunk.,szakisk. $\square$ szakköz.éretts.,középf.tech.

$\square$ szakképzés (középisk.utáni, $\square$ felsőf.akkr.szakképzés felsőf.nem akkr.)

$\square$ egyetemi szintü osztatlan képz.szerz.dipl.

$\square$ egyetemi alapképzés(BA

tudom.fokoz.(Ph.D;DLA)

(BSc)

$\square$ NT

$\square 8$ ált.

gimn.éretts.

föisk.szintü osztatlan képz. szerz.dipl.

$\square$ mesterképzés MA (MSc)

$\square \mathrm{NV}$

!!KÉRDEZŐ: CSAK AZOKNAK FELTENNI, AKIK AZ ELŐZŐ KÉRDÉSNÉL A "kevesebb, mint 8 oszt." VÁLASZTOTTÁK!!

Mi az oka annak, hogy Ön nem fejezte be a 8 általánost?

3.2 még jelenleg is általános iskolás

3.3 be fogja fejezni, csak most valamilyen okból szünetet tart

3.4 nem sikerült befejeznie az iskolaköteles kor végéig

3.5 rosszul tanult, abbahagyta

3.6 családi okokból abbahagyta (esküvő, gyerek)

3.7 anyagi okokból abbahagyta (inkább elment dolgozni)

3.8 magántanuló

3.9 Más okból, éspedig:
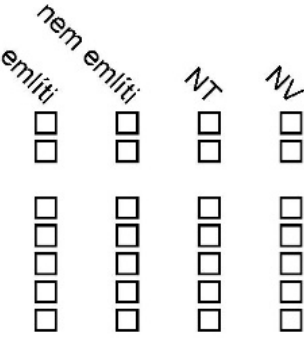
\begin{tabular}{l|l} 
EvaSys & \\
3. OKTATÁS [Folytatás]
\end{tabular}

Nyíregyháza ifjúsága 2015

Az alábbiak közül melyik igaz Önre? (TÖBB VÁLASZADÁSI LEHETÖSÉG!)

3.10 Tanul, részt vesz valamilyen iskolában vagy

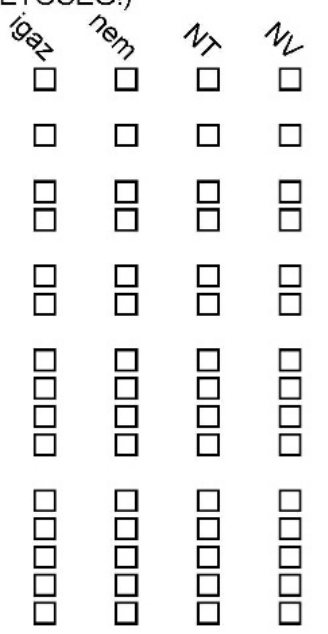

tanfolyamon valamilyen képzésben.

3.11 Dolgozik, akár bejelentve, akár nem, akár alkalmazottként, akár vállalkozóként.

3.12 munkanélküli, álláskeresési járadékot kap

3.13 álláskeresési támogatásban részesülő közhasznú foglalkoztatott

3.14 munkanélküli, ellátás nélkül

3.15 terhességi-gyermekágyi segélyen van (TGYÁS-on van)

3.16 GYED-en van

3.17 GYES-en van

3.18 GYET-en van

3.19 háztartásbeli, otthon van a gyerekekkel (GYED, GYES, GYET nélkül)

3.20 eltartott, otthon

3.21 rokkantnyugdíjas, rokkantjáradékos

3.22 (más)nyugdíjas

3.23 szociális segélyezett

3.24 egyéb inaktiv

3.25 Melyiket tekinti főtevékenységnek az alábbiak közül? (CSAK EGYET VÁLASZTHAT!)
$\square$ Tanul, részt vesz valamilyen iskolában vagy tanfolyamon
$\square$ Dolgozik, akár bejelentve,
akár nem, akár
munkanélküli, álláskeresési valamilyen kèpzésben.(1) alkalmazottként, akár járadékot kap
$\square$ álláskeresési támogatásban vállalkozóként. részesülö, közhasznú
$\square$ munkanélküli, ellátás nélkül
$\square$ terhességi-gyermekágyi foglalkoztatott
$\square$ GYED-en van
GYET-en van segélyen van (TGYÁS-on)
$\square$ eltartott, otthon van
$\square$ szociális segélyezett
rokkantnyugdijas, rokkantjáradékos
$\square$ egyéb inaktiv
háztartásbeli, otthon van a gyerekekkel (GYED, GYES, GYET nélkül) $\square$ (más) nyugdijas
$\square$ NT

$\square \mathrm{NV}$

!!KÉRDEZŐ: HA AZ ELŐZZŐ KÉRDÉSNÉL AZ 1-ES OPCIÓT VÁLASZTOTTA, AKKOR FEL KELL TENNI A KÖVETKEZÓ KÉRDÉSEKET: 3.26-3.39.!!

3.26 Milyen iskolába jár Ön jelenleg?
$\square$ ált.iskolába
$\square$ gimnáziumba $\square$ főiskolára (régi, osztatlan
$\square$ mesterképzés (MA;MSc)

$\square$ szakmunk.,szakisk.

szakképzés (éretts.utáni, felsöf.nem akkr.)

$\square$ egyetemre (régi osztatlan képz.)

$\square$ doktori képz.(Ph.D;DLA)

$\square$ egyéb tanf.végez,nem isk.rsz.-

$\square$ NT ben

3.27 Milyen tagozatra jár?

$\square$ nappali

$\square$ távoktatás

$\square \stackrel{N V}{ }$

$\square$ esti

szakköz.éretts.,középf.tech

felsöf.akkr.szakképzés

$\square$ alapképzésben(BA (BSc)

dipl.utáni, szakir.tov.képz. posztgrad.képz.

$\square \mathrm{NV}$

levelező

NT 


\section{EvaSys \\ 3. OKTATÁS [Folytatás]}

Nyíregyháza ifjúsága 2015

3.28 Az Ön iskolája más településen van-e, mint az otthona, az állandó lakóhelye?

$\square$ igen

$\square$ nem (UGRÁS: 3.30. kérdésre) $\square$ NT

3.29 Milyen idöközönként jár iskolába?

$\square$ naponta bejár

$\square$ ennél ritkábban ingázik?

$\square$ NT

$\square \mathrm{NV}$

3.30 Mennyi idő alatt jut el Ön otthonról (ahol lakik) az iskolájába? (...PERC)

3.31 Mennyi idõ alatt jut el Ön otthonról (ahol lakik) az iskolájába?

3.32 Milyen finanszírozású oktatásban vesz részt?

$\square$ költségtéritéses (fizetös)

$\square$ egyéb

$\square$ részfinanszírozás (nem a teljes kségtér.fizeti)

$\square$ NT

3.33 Hány ezer forint költségtéritést fizet a mostani félévre?

$\square$ ideiglenesen ott lakik (kollégiumban, albérletben, stb.)

100.

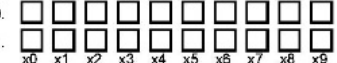

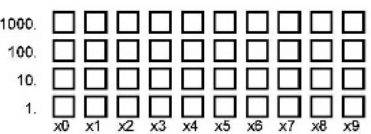

3.34 Jelenleg igénybe vesz-e Ön diákhitelt tanulmányai finanszirozásához?
$\square$ igen
$\square$ jelenleg nem, de régebben
$\square$ nem (UGRÁS: 3.38-ra) volt diákhitele
$\square$ NT
NV
3.35 Melyik Diákhitel konstrukciót vette/veszi igénybe?
$\square$ a saját szlájára érk.havonta, v. $\square$ a kségtér.képz.kifiz.-hez, a félévente pénz
Diákhit.Közp. kvetlenül az isk.-
mindkettő
$\square$ NT
$\square$ NV

jelenleg nem, de tervezi

(UGRAS: 3.37-re)

3.36 Elsősorban mire költi/költötte Ön a diákhitelt?

$\square$ a kségtér.befizetésére $\quad \square$ egyéb tanulmányi kségekre

$\square$ arra, h. követni tudja a normális egyetemista

életformát (szórakozás,

teljes egészében államilag tám. (UGRAS: 3.34-re)

$\square \mathrm{NV}$

NV kultúra,sport,stb.)

$\square N V$

(tartós fogy.cikk,turizmus stb.)

$\square$ megélhetési kségek (pl. étkezés, lakhatás, közlek.) fedezésére (ide nem értve a szórakozást, kultúrát, sportot)

3.37 Véleménye szerint gondot okoz-e (majd) Önnek a havi törlesztő részletek fizetése?
$\square$ egyáltalán nem
$\square$ kismértékben
$\square$ nagy gondot okoz majd

3.38 Reményei szerint a tanulmányai befejezése után mennyi időn belül tud elhelyezkedni?

$\square$ legfeljebb 1 hónapon belül

$\square$ ennél hosszabb idő alatt

$\square$ néhány hónapon belül

egyáltalán nem tud elhelyezkedni

$\square$ fél éven belül

$\square$ NT

$\square \mathrm{NV}$

már abban a szakmában dolgozik, amit éppen tanul 
\begin{tabular}{l|c|c|} 
EvaSys & Nyíregyháza ifjúsága 2015 & Electric Paper \\
\hline
\end{tabular}

3. OKTATÁS [Folytatás]

3.39 Hány éves korában fejezte be a tanulmányait?

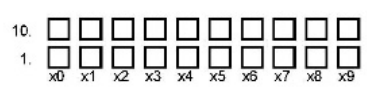

3.40 Kérem, mondja meg, melyik állítás igaz Önre?

$\square$ a tanulmányait véglegesen és $\square$ a tanulmányait sikeresen

sikeresen befejezte befejezte, ugyanakkor

(UGRÁS:3.46-ra)

elképzelhető, hogy a

késóbbiekben tanulni fog még

$\square$ a tanulmányait félbehagyta de nem fogja/nem kívánja (UGRÁS:3.46-ra)

folytatni

$\square$ a tanulmányait félbehagyta de elképzelhetö, hogy folytatni fogja

$\square N V$

\section{Miért nem fejezte be Ön ezt az iskolát? NYITOTT KÉRDÉS!}

3.41 be fogja fejezni, csak most valamilyen okból szünetet

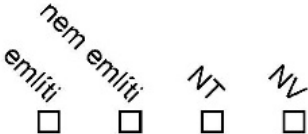

tart

3.42 rosszul tanult, abbahagyta

3.43 családi okokból abbahagyta (pl. esküvö, gyerek)

3.44 anyagi okokból abbahagyta (inkább elment dolgozni)

3.45 Más okból, éspedig:

3.46 Szeretne-e továbbtanulni, tanfolyamot végezni, tanulni még valamit?
$\square$ igen
nem (UGRÁS: 3.61-3.68-ra)
$\square$ még nem gondolkozott rajta

Mit szeretne még tanulni? Kérem sorolja fel az összes olyan iskolát, tanfolyamot, amit a jövöben el szeretne végezni! NYITOTT KERDES!

\subsection{7 (másik) szakmát tanulna}

3.48 érettségizni szeretne

3.49 középfokú technikumban tanulna

3.50 középiskola utáni, felsőfokra nem akkreditált szakképzésben venne részt

3.51 felsöfokú, akkreditált szakképzésben venne részt

3.52 egyetemi alapképzésben venne részt BA (BSc)

3.53 egyetemi mesterképzésben venne részt MA (MSc)

3.54 fóiskolai szintü osztatlan képzésben venne részt

3.55 egyetemi szintü osztatlan képzésben venne részt

3.56 tudományos fokozatot szerezne (PhD., vagy DLA képzésben venne részt

3.57 nyelvet tanulna

3.58 más tanfolyamon venne részt, éspedig:
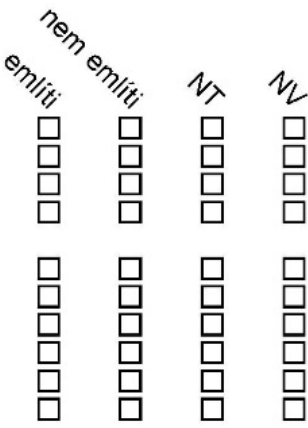

\section{más tanfolyamon venne részt, éspedig:}




\begin{tabular}{|c|c|c|}
\hline EvaSys & Nyíregyháza ifjúsága 2015 & Electric Paper \\
\hline \multicolumn{3}{|l|}{ OKTATÁS [Folytatás] } \\
\hline \multicolumn{3}{|c|}{$\begin{array}{l}59 \text { Kérjük, nevezze meg a KÉT LEGFŐBB okot, ami miatt Ön a jövőben még tanulni szeretne! } \\
\text { NYITOTT KÉRDÉS! }\end{array}$} \\
\hline $\begin{array}{l}\square \text { hogy jól/minél jobban fizetö } \\
\text { állást szerezhessen }\end{array}$ & $\begin{array}{l}\square \text { manapság megfelelö } \\
\text { végzettség nélkül nincs esély } \\
\text { normális életre }\end{array}$ & $\begin{array}{l}\square \text { hogy azzal foglalkozhasson, } \\
\text { amivel szeret }\end{array}$ \\
\hline$\square$ családja, környezete elvárása & $\begin{array}{l}\square \text { szeret tanulni, új dolgokat } \\
\text { megismerni }\end{array}$ & $\begin{array}{l}\square \text { később kell eldöntenie, milyen } \\
\text { pályát válasszon, mit kezdjen } \\
\text { magával }\end{array}$ \\
\hline $\begin{array}{l}\square \text { természetes, hogy (további) } \\
\text { végzettséget szerezzen, } \\
\text { sosem gondolta másképp }\end{array}$ & $\begin{array}{l}\square \text { ma már nélkülözhetetlen a } \\
\text { folyamatos tanulás }\end{array}$ & $\square$ egyéb \\
\hline$\square$ NT & $\square \mathrm{NV}$ & \\
\hline
\end{tabular}

3.60 Amennyiben az előző kérdésnél az "egyéb" opciót választotta, mondja el mire gondolt!

Ön szerint a következők mennyire szükségesek ahhoz, hogy az ember jó állást tudjon találni? (1= egyáltalán nem szükséges.....5=teljes mértékben szükséges)

3.61 nyelvtudás

3.62 jó kapcsolatok

3.63 protekció

3.64 jó családi háttér

3.65 szaktudás, hozzáértés

3.66 jó iskolai papírok

3.67 szakmai gyakorlat

3.68 állandó tanulás, képzések

3.69 Véleménye szerint lesz-e valaha olyan munkája, amely legalábbis megközelíti azt amire vágyik?

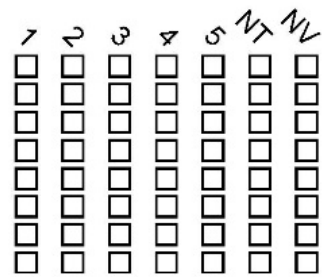

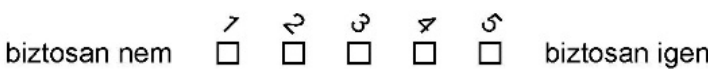

3.70 Véleménye szerint lesz-e valaha olyan munkája, amely legalábbis megközelíti azt amire vágyik?
$\square$ már most az van
$\square$ NT
$\square$ NV

Mennyire tartja fontosnak az alábbi szempontokat munkahelyválasztás során? ( $1=$ egyáltalán nem fontos;.... 5=teljes mértékben)

3.71 jó fizetés

3.72 önálló munkavégzés

3.73 jó időbeosztás

3.74 érdekes munka

3.75 jó munkakörülmények

3.76 kevés stressz

3.77 szakmai fejlődési lehetőségek

3.78 elörejutási lehetőségek

3.79 társadalmilag hasznos munka

3.80 biztos munkahely

3.81 lakóhelyhez közel lévő munkahely

3.82 munkáltató/cég hírneve

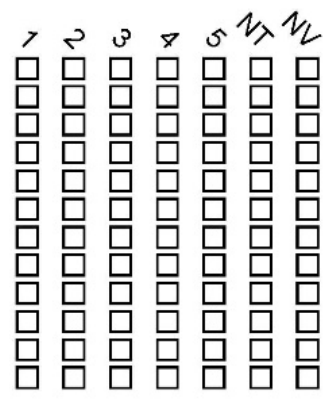




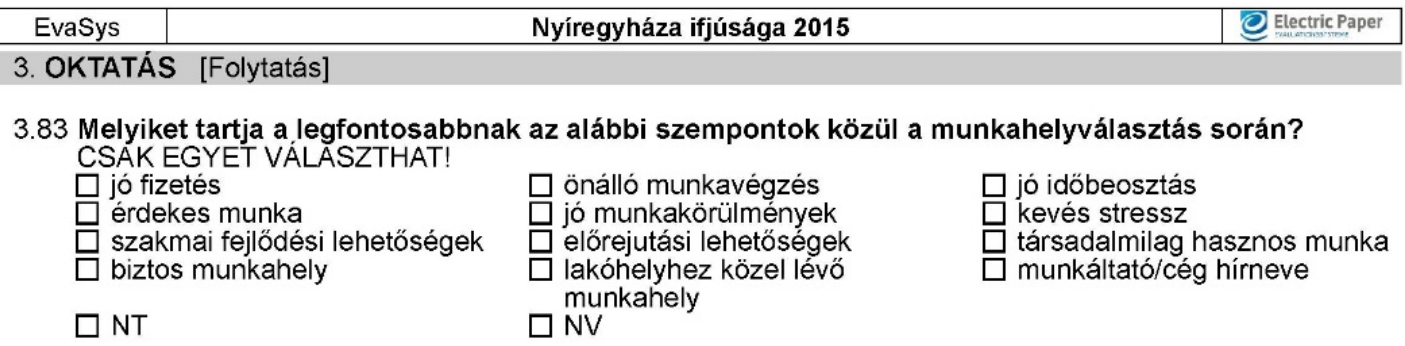

3.84 Beszél-e Ön/használ-e Ön valamilyen idegen nyelvet?
$\square$ igen
nem (UGRÁS: követk. blokkra)
$\square$ nem a magyar az anyanyelve

3.85 Hány nyelvet beszél?

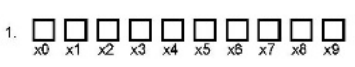

3.86 Hány nyelvet beszél?

$\square$ NT

$\square \mathrm{NV}$

3.87 Milyen nyelven beszél? TÖBB VÁLASZTÁS LEHETSÉGES!
$\square$ angol $=1$
cigány (lovári, beás $)=7$
$\square$ francia $=2$
$\square$ orosz $=5$
$\square$ kinai $=8$
$\square$ horvát=11
$\square$ német=3
$\square$ spanyol=6
román $=9$
szlovák $=10$
$\square$ szerb=12

3.88 Amennyiben az előző kérdésnél az "egyéb" opciót választotta, írja le mire gondolt!

3.89 Melyiket tartja az ELSŐ legfontosabbnak?

3.90 Milyen szinten beszéli?
$\square$ anyanyelvi szinten

$\square$ alapfokon

3.91 Milyen nyelvvizsgája van?

$\square$ felső

nincs nyelvvizsgája

3.92 Hol tanulta a nyelvet?

$\square$ iskolában

$\square$ NT

.93 Melyiket tartja a MÁSODIK legfontosabbnak?

3.94 Milyen szinten beszéli?

$\square$ anyanyelvi szinten

alapfokon

$\square$ NV

3.95 Milyen nyelvvizsgája van?

$\square$ felső

nincs nyelvvizsgája

$3.96 \mathrm{Hol}$ tanulta a nyelvet?

$\square$ iskolában

$\square$ NT $\square$ felsö fokon

$\square$ közép

$\square$ NT

$\square$ iskolán kívül

NV $\square$ közép
$\square$ NT

$\square$ iskolán kívül

$\square$ NV

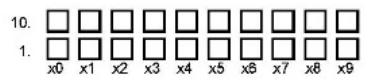

$\square$ középfokon

$\square$ NT

$\square$ alap

NV

$\square$ mindkettő

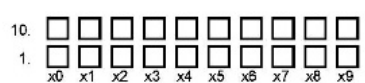

$\square$ középfokon $\square$ NT

$\square$ alap

$\square$ mindkettő

felső fokon
nem beszéli

mindketo 

EvaSys
Nyíregyháza ifjúsága 2015
3. OKTATÁS [Folytatás]
3.97 Melyiket tartja a HARMADIK legfontosabbnak?
3.98 Milyen szinten beszéli?
$\square$ anyanyelvi szinten
$\square$ alapfokon
$\square$ felső fokon
$\square$ nem beszéli
$\square$ közép
$\square$ felsó
$\square$ NT
$\square$ iskolán kívül
$\square$ iskolában
$\square$ középfokon
NT

\section{alap}
$\square$ mindkettő

$\square$ NV

$\square$ NT

Szokta-e Ön idegennyelvtudását az alábbiakhoz használni?

3.101munkájához

3.102tanuláshoz

3.103idegennyelvủ újságot, magazint olvasni

3.104idegennyelvü internetes cikkeket olvasni

3.105társalogni élö szóban

3.106társalogni írásban

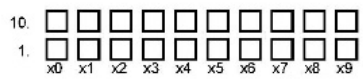

\subsection{Tanult-e valaha külföldön?}

$\square$ igen

$\square$ nem (UGRÁS: követk. blokkra) $\square$ NT

3.108Mennyi időt töltött el összességében külföldi tanulással? (hónap)

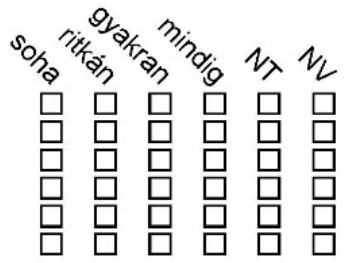

3.109Mennyi időt töltött el összességében külföldi tanulással? (hónap)

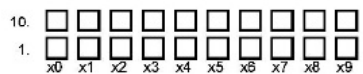

\section{MUNKAERŐPIAC}

4.1 Eddigi élete során végzett-e olyan munkát, amiért pénzt kapott?

$\square$ igen

$\square$ nem (UGRÁS: 4.18-ra)

$\square$ NT

Amikor legutóbb sikerült elhelyezkeḍnie, a legutóbbi/jelenlegi munkahelyére, kitől kapta a legnagyobb segítséget? NYITOTT KÉRDÉS!
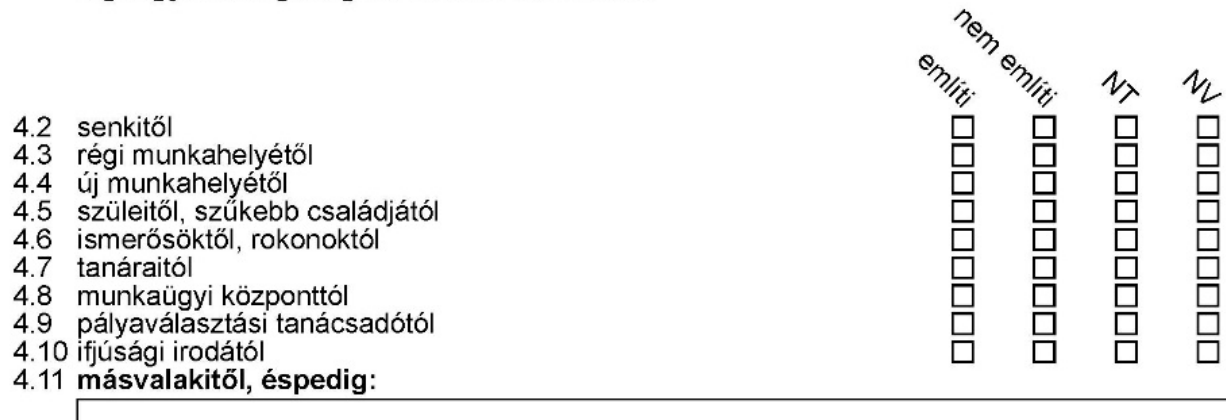


\begin{tabular}{|c|c|c|}
\hline \multirow[t]{2}{*}{ EvaSys } & \multirow[t]{2}{*}{ Nyíregyháza ifjúsága 2015} & (2) Electric Par \\
\hline & & \\
\hline
\end{tabular}

4.13 Hány éves korában történt az először, amikor munkavégzésért pénzt kapott?
$\square$ NT
$\square \mathrm{NV}$

Dolgozott-e bármikor az iskola mellett...

4.14 iskolai szünidöben (pl. nyári szünet)?

4.15 iskola idő alatt (pl. reggelenként iskola elött, tanitás után, hétvégenként)?

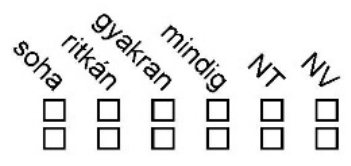

4.16 Volt már Önnek legalább 3 hónapig tartó munkavállalása, leszámítva a szünidei munkavállalásokat?
$\square$ igen
$\square$ nem (UGRÁS: 4.18-ra)
$\square$ NT

4.17 Hány éves korában volt először ilyen munkája?

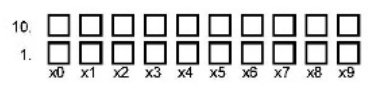

4.18 Mit gondol, hány éves korában lesz először ilyen munkája?

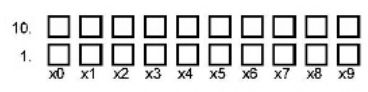

4.19 Iskolái befejezése/abbahagyása után hány hónappal tudott elöször elhelyezkedni? (hónap)

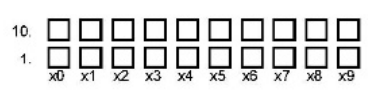

4.20 Iskolái befejezése/abbahagyása után hány hónappal tudott először elhelyezkedni? (hónap) $\square$ kevesebb, mint 1 hónappal $\square$ már a tanulmányai alatt

$\square$ még nem sikerült

$\square$ NT

$\square$ NV

4.21 Hány munkahelye (legalább 3 hónapig tartó munkavállalása) volt eddig?

(ha "O" a válasz, UGRÁS: 4.55-4.58-ra)

4.22 Hány munkahelye (legalább 3 hónapig $\square$ NT $\square$ NV tartó munkavállalása) volt eddig?

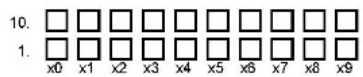

4.23 Jelenleg hány különböző munkája, munkahelye van Önnek?

4.24 Jelenleg hány különböző munkája, $\square$ NT $\quad \square$ NV

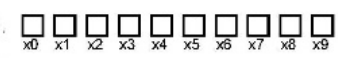
munkahelye van Önnek? 


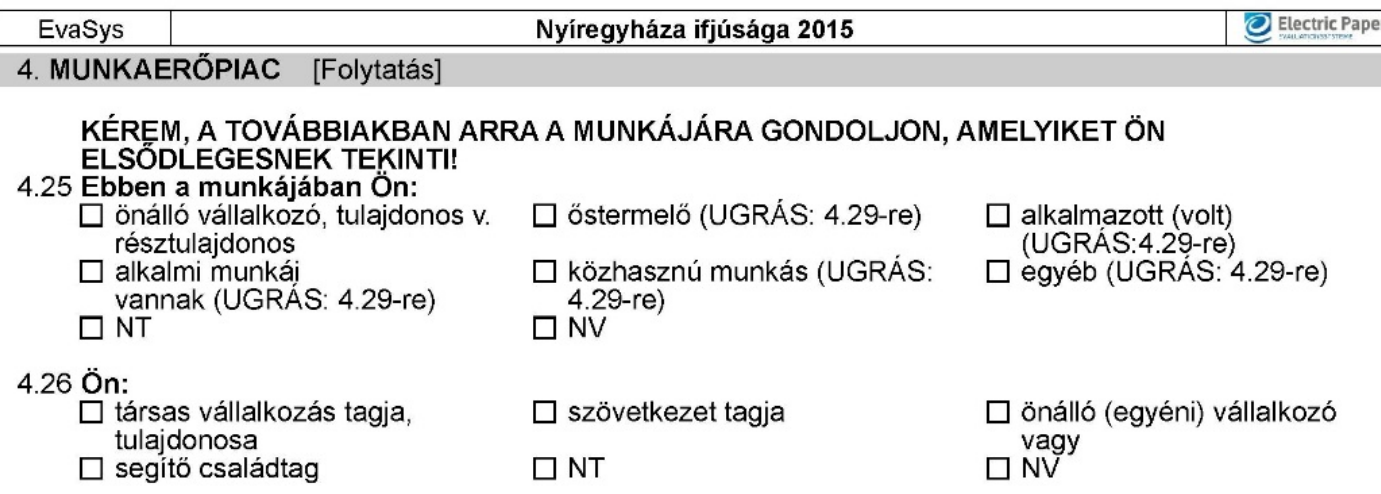

$\square$ önálló vállalkozó, tulajdonos v. $\quad \square$ östermelö (UGRÁS: 4.29-re) résztulajdonos

$\square$ alkalmi munkái vannak (UGRÁS: 4.29-re)

$\square$ NT

$\square$ közhasznú munkás (UGRÁS: 4.29-re)

$\square \mathrm{NV}$

4.26 Ön:
társas vállalkozás tagja, tulajdonosa
$\square$ segítö családtag
$\square$ szövetkezet tagja
$\square$ NT

alkalmazott (volt) (UGRÁS:4.29-re)

$\square$ egyéb (UGRÁS: 4.29-re)
$\square$ önálló (egyéni) vállalkozó vagy

NV

4.27 Hány alkalmazottja van/volt Önnek?

4.28 Hány alkalmazottja van/volt Önnek?

$\square$ NT

$\square N V$

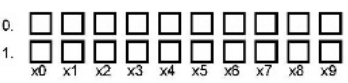

4.29 Milyen típusú munkaszerződése van (volt az utolsó munkájában) Önnek?
határozatlan idejü, bejelentett
$\square$ alkalmazottként számlát adok egy cég nevében
határozott idejü, bejelentett
bejelentés nélküli alkalmazásban ál
$\square$ NT

$\square$ eseti megbízás

$\square \mathrm{NV}$

$4.30 \mathrm{Mi}$ (volt) a FOGLALKOZÁSA? fizikai

$\square$ mg-i fizikai munkás

$\square$ szakmunkás (nem mg-i)

segédmunkás (nem mg-i)

közvetlen termelésirányító ( $p l$. múvezető)

4.31 Mi (volt) a FOGLALKOZÁSA? szellemi

$$
\begin{aligned}
& \square \text { egyéb } \\
& \text { (diplomához } \\
& \text { nem kötött) } \\
& \text { szellemi }
\end{aligned}
$$

$\square$ betanított munkás (nem mg-i)

$4.32 \mathrm{Mi}$ (volt) a FOGLALKOZÁSA? vezetó

$\square$ felsö vezetö (osztvez.felett)

$\square$ középszintü vez. (osztvez.)

$\square$ alsó vezetö (osztvez.alatt)

$4.33 \mathrm{Mi}$ (volt) a FOGLALKOZÁSA?

$\square$ NT

$\square N V$

4.34 Mennyi ideje dolgozik/dolgozott itt? (hónap)

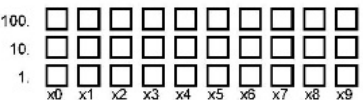
4.35 Mennyi ideje dolgozik/dolgozott itt?
$\square$ NT
NV

4.36 Ön a fizetését részben vagy egészben zsebbe kapja-e (kapta)?

$\square$ igen, az egészet

$\square$ igen, egy részét

$\square$ nem, semennyit sem kap zsebbe

$\square$ NT

$\square \mathrm{NV}$

4.37 Mennyi (volt) az Ön munkája, vállalkozása után kapott átlagos havi nettó jövedelme? (...ezerFt) Kérem, a juttatásokat most ne vegye figyelembe!

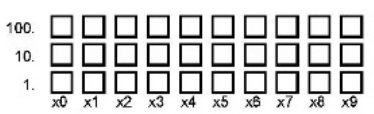

4.38 Mennyi (volt) az Ön munkája, vállalkozása után kapott átlaqos havi nettó iövedelme? Kérem, a juttatásokat most ne vegye figyelembe!

$\square \mathrm{NV}$

$\square$ NT 


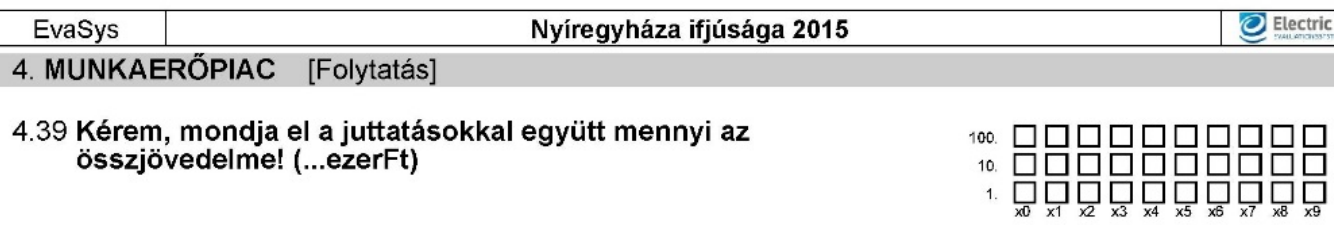

4.40 Milyen munkaidőben dolgozik (dolgozott)?
$\square$ teljes munkaidőben
$\square$ részmunkaidőben dolgozik/
$\square$ NT
$\square$ NV
dolgozott

4.41 Más településen volt-e/van-e a munkahelye, mint ahol lakik/lakott?
$\square$ igen
$\square$ NT
$\square$ igen, külföldön
$\square$ nem ((UGRÁS: 4.43-ra)

4.42 Milyen rendszerességgel ingázik/ingázott?
$\square$ naponta
$\square$ havonta vagy ritkábban
$\square$ hetente
$\square$ NT
$\square$ kéthetente
NV 4.43 Mennyi idő alatt jut/jutott el Ön otthonról (ahol lakik)
munkahelyére, munkavégzésének helyére? (...PERC)

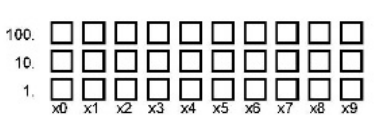

4.44 Mennyi idő alatt jut/jutott el Ön otthonról (ahol lakik) munkahelyére, munkavégzésének helyére? $\square$ változó

$\square$ NT

$\square \mathrm{NV}$
4.45 Mennyire érzi biztosnak jelenlegi munkáját,
állását?
(1=egyáltalán nem biztos;....5=teljes mértékben biztos)

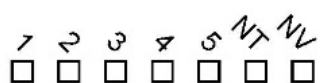

HA NEM DOLGOZIK JELENLEG

Miért ért véget ez a munka, munkaviszony? NYITOTT KÉRDÉS!

4.46 elégedetlen volt, kilépett (fizetéssel, munkahellyel stb.)

4.47 férjhez ment, megnösült, ezért kilépett

4.48 gyermeket vállalt

4.49 egyéb családi ok miatt kilépett

4.50 egészségügyi okok miatt kilépett

4.51 felmondtak

4.52 lejárt a szerződése

4.53 visszament tanulni

4.54 partnere munkája miatt hagyta ott

4.55 megszünt a cég

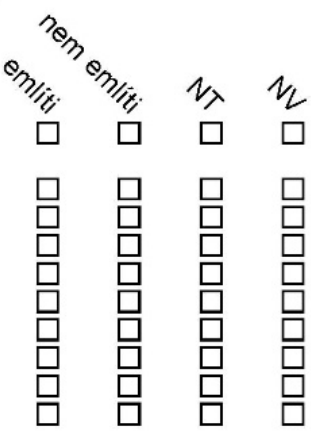

Volt-e eddigi élete során bármikor...?

4.56 regisztrált munkanélküli

4.57 nem regisztrált munkanélküli

4.58 mindkettö volt

4.59 nem volt munkanélküli (UGRÁS: 4.66-ra)

4.60 Hányszor volt Ön összesen munkanélküli? (alkalommal)

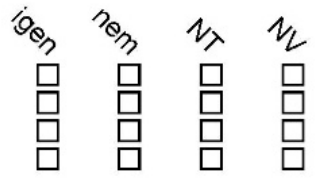

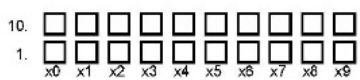




\begin{tabular}{c|ccc}
\hline EvaSys & Nyíregyháza ifjúsága 2015 & \\
4. MUNKAERŐPIAC [Folytatás] & & \\
$\begin{array}{l}\text { 4.61 Hányszor volt Ön összesen } \\
\text { munkanélküli? }\end{array}$ & $\square \mathrm{NT}$ & $\square \mathrm{NV}$
\end{tabular}

4.62 Mennyi ideig tartott a leghosszabb munkanélküli időszaka? (hónap)

4.63 Mennyi ideig tartott a leghosszabb munkanélküli időszaka?

$\square N T \quad \square N V$

4.64 Ön regisztrált munkanélküli vagy sem?
吕igen
$\square$ nem
$\square$ NT

4.65 Miért nem regisztrált?
$\square$ fölösleges kötelezettségekkel
$\square$ már lejárt úgyis a járadék
$\square$ úgysem tudnak segíteni munkát találni
$\square$ azt reméli, nagyon hamar talál $\quad \square$ NT munkát
$\square$ nem tudtam, hogy kell/lehet $\square$ NV

4.66 Tapasztalatai szerint milyenek most az $>23 \times s v_{\lambda} v_{L}$ elhelyezkedési lehetőségek az Ön lakóhelyén és a környékén azzal a végzettséggel és

szakképzettséggel, amellyel On rendelkezik /

amilyen végzettséggel Ön iskolái befejezése után

rendelkezni fog?

( $1=$ nagyon kedvezötlen...... 5=nagyon kedvezöek)

4.67 Jelenleg keres-e Ön munkát?

$\square$ igen (UGRÁS: 4.78-ra)

$\square$ nem

$\square$ NT

NV

Miért nem keres munkát?

4.68 mert van munkája, meg van vele elégedve

4.69 úgysem talál a környéken

4.70 úgysem talál megfelelőt

4.71 úgysem talál olyat, amelyik jól fizet

4.72 gyereket szeretne vállalni

4.73 el szeretne költözni

4.74 más családi okokból

4.75 tanulnia kell még, átképeznie magát

4.76 jelenleg is tanul

4.77 alkalmi munkái, bejelentetlen munkája így is van, nem akar keresni

4.78 Mit gondol, mennyi idõ múlva fog tudni elhelyezkedni?
1-2 héten belül
3-4 héten belül
3-4 hónapon belü
5-6 hónapon belül
$\square$ nem fog tudni elhelyezkedni
$\square$ NT

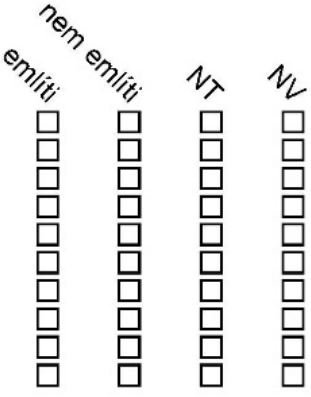

4.79 Dolgozott-e valaha külföldön?

$\square$ igen

$\square$ nem (UGRÁS: követk.blokkra) $\quad \square$ NT belül 
EvaSys

4. MUNKAERÖPIAC [Folytatás]

Nyíregyháza ifjúsága 2015

4.80 Hány éves volt, amikor legelőször külföldön vállalt munkát?

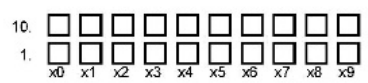
4.81 Hány éves volt, amikor legelőször
$\square \mathrm{NT}$
$\square \mathrm{NV}$ külföldöon vállalt munkát?

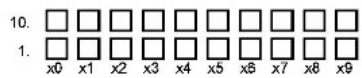

4.82 Összesen hány hónapot dolgozott külföldön?
4.83 Összesen hány hónapot dolgozott
$\square$ NT
NV külföldön?

$4.84 \mathrm{Hol}$ dolgozott, melyik országban?

\section{KÜLFÖLDI MUNKA ÉS TANULÁS}

5.1 Volt-e már külföldön? $\square$ igen

$\square$ nem (UGRÁS: 5.4-re)
$5.2 \mathrm{Ha}$ igen, milyen céllal?
$\square$ tanulás
egyéb
$\square$ nyaralás
$\square$ munka

5.3 Amennyiben az előzős kérdésnél az "egyéb" pozíciót választotta, kérem mondja meg, mire gondolt?

5.4 Amennyiben lenne lehetősége arra, hogy külföldön tanuljon, dolgozzon, hajlandó lenne-e elhagyni az országot hosszabb-rövidebb idöre?

$\square$ nem, csak Mo-on tudja elképzelni az életét (UGRÁS:5.7-5.15-re)

igen, de csak egy hónapnál
rôvidebb idöre

$\square$ igen, akár fél évnél hosszabb idöre is

$\square$ NT

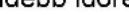

$\square$ igen, de csak 1 és 6 hónap

$\square$ igen, akár 5 évnél hosszabb idöre is közötti idöre

$\square \mathrm{NV}$

$\square$ igen, akár végleges letelepedés céljából is

5.5 Tervezi-e, hogy a jövőben külföldön tanul?

$\square$ igen $\quad \square$ nem $\quad \square$ NT

$\square \mathrm{NV}$

口

$\square$ NT

5.6 Tervezi-e, hogy valaha külföldön fog dolgozni?

ㅁigen

$\square$ nem

Az alábbiak közül mi az, amiért (mégis) hajlandó lenne elhagyni az országot hosszabb-rövidebb idöre?

5.7 karrier

5.8 jobb megélhetés

5.9 tapasztalatszerzés

5.10 új kihivások

5.11 tanulás általában (Mo.-on nincs olyan képzés, több tanulási lehetöség van, stb.) NEM nyelvtanulás

5.12 nyelvtanulás

5.13 politikai/ideológiai okok

5.14 családi okok

5.15 hogy önkéntes munkát végezzen

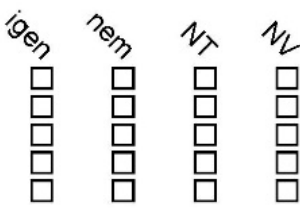

F7028U14782P17PLOV1
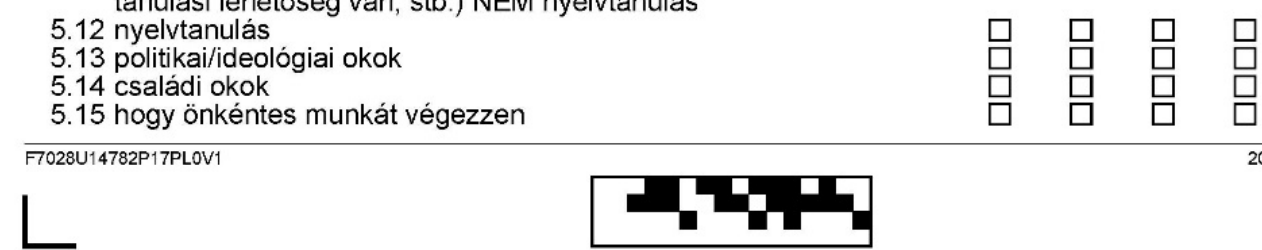
\begin{tabular}{|l|c|c|} 
EvaSys & Nyíregyháza ifjúsága 2015 & Electric Paper \\
\hline
\end{tabular}

5. KÜLFÖLDI MUNKA ÉS TANULÁS [Folytatás]

Mennyire tartják vissza a következők attól, hogy hosszabb-rövidebb időre elhagyja az országot? $1=$ egyáltalán nem tartja vissza....5=teljes mértékben visszatartja)

5.16 ragaszkodik a hazájához, szülőhelyéhez

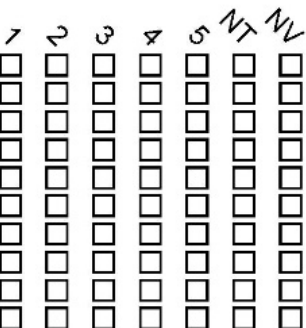

5.17 ragaszkodik a barátaihoz

5.18 ragaszkodik a családjához

5.19 egyedül nem mer belevágni

5.20 nincs (anyagi) lehetősége rá

5.21 túlságosan sok ügyintézéssel jár

5.22 nem akarja föladni itthoni életét, karrierjét

5.23 nem beszél elég jól idegen nyelven

5.24 azt sem tudja, hogyan fogjon hozza

5.25 itthon is boldogul

Ön mire lenne hajlandó egy kedvezöbb munkalehetőség (megszerzésének) érdekében? $1=$ biztosan nem;....5=biztosan igen)

5.26 elköltözni egy másik településre (városba)

5.27 elköltözni egy másik megyébe

5.28 naponta több órát utazni

5.29 elköltözni egy másik országba

5.30 megtanulni egy (újabb) nyelvet

5.31 megtanulni egy (újabb) szakmát

5.32 Mennyi lenne az a maximális idő amit Ön hajlandó lenne utazni munkahelyére? (PERC)
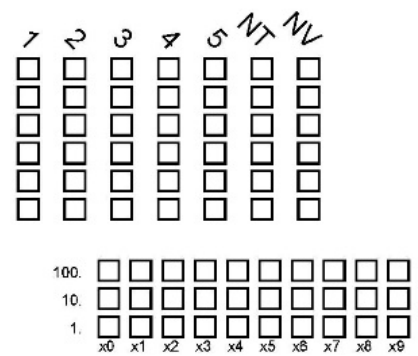

5.33 Mennyi lenne az a maximális idő amit $\quad \square$ NV $\quad \square$ NT

Ön hajlandó lenne utazni

munkahelyére?

Mennyire tartja Ön valószínűnek, hogy néhány éven belül igazak lesznek Önre a következő kijelentések?

(1=egyáltalán nem;....5=teljes mértékben)

5.34 új munkahelyen dolgozik

5.35 saját vállalkozást indít

5.36 külföldön tanul tovább

5.37 megtanul egy új nyelvet

5.38 külföldön vállal munkát

5.39 távmunkában dolgozik otthonról

5.40 elköltözik egy másik településre

5.41 elköltözik egy másik országba

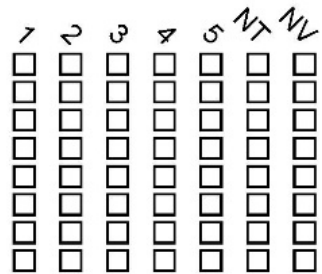


EvaSys

6. KÖZÉLETI KÉRDÉSEK (5)

Nyíregyháza ifjúsága 2015

Kapcsolódik-e Ön valamilyen módon a következó szervezetekhez?

(1=tagja; 2=részt vesz a munkájukban; 3=néha elmegy a rendezvényeikre; 4=nem kapcsolódik;)

6.1 diákszervezet

6.2 szabadidős szervezet, csoport

6.3 kulturális, hagyományörző, müvészeti csoport, szervezet

6.4 sportklub vagy egyesület

6.5 környezetvédelmi, természetvédelmi, állatvédő szervezet

6.6 lelki, szociális problémákkal foglalkozó szervezet

6.7 jótékonysági szervezet

6.8 egyházi szervezet, vallási közösség (nem egyház!!)

6.9 emberjogi mozgalom vagy szervezet

6.10 békemozgalom

6.11 szakszervezet

6.12 szakmai egyesület

6.13 más érdekvédelmi szervezet

6.14 politikai ifjúsági szervezet

6.15 más ifjúsági szervezet

6.16 politikai párt

6.17 polgári kör

6.18 polgárörség

6.19 határon túli vagy határon túliakkal foglalkozó szervezet

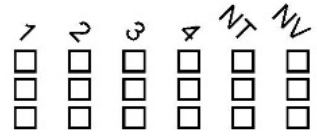

6.20 egyéb, éspedig:

IKÉRDEZŐ: ADD ODA AZ 1.SZ. VÁLASZLAPOT!!

6.21 Az alábbiak közül ma Mo-on melyik az ifjúság legégetőbb problémája?
$\square$ alkohol elterjedése $\square$ baráti társaság hiánya
$\square$ búnözés

$\square$ céltalanság, nem tudják, mit

$\square$ család válsága, hiánya akarnak

$\square$ egészségtelen,

$\square$ erkölcsi romlás mozgásszegény életmód

$\square$ isk.problémák, tanulási

$\square$ kilátástalan, bizonytalan jövő

drogok kábítószerek nehézségek

$\square$ környezet rossz állapota (rossz levegö, piszok)

$\square$ közlekedési nehézségek

elterjedése

$\square$ fiatalok ált.rossz helyzete igénytelenség

$\square$ megfelelö isk.hiánya v. elérhetetlensége

$\square$ lakásproblémák

$\square$ korrupció penztelenseg,szer

$\square$ mnélküliség, elhelyezk. nehézség elszegényedés

$\square$ rossz családi körülmények

$\square$ egyéb

$\square$ közösség hiánya

$\square$ létbizonytalanság

$\square$ önálló egzisztencia, család megteremtése

szórakozási és ismerkedési lehetőségek hiánya

$\square$ szülőktől való függés 
EvaSys

Nyíregyháza ifjúsága 2015

? Electric Paper

6. KÖZÉLETI KÉRDÉSEK (5) [Folytatás]

6.22 Az alábbiak közül ma Mo-on melyik az ifjúság második legégetőbb problémája?

$\square$ alkohol elterjedése
$\square$ céltalanság, nem tu

$\square$ baráti társasáág hiánya akarnak

$\square$ egészségtelen,

mozgásszegény életmód

$\square$ isk.problémák, tanulási nehézségek

$\square$ környezet rossz állapota (rossz levegó, piszok)

$\square$ kulturálatlanság, tudatlanság, igénytelenség

$\square$ megfelelő isk.hiánya $v$. elérhetetlensége

$\square$ pénztelenség,szegénység elszegényedés

$\square$ család válsága, hiánya

$\square$ bűnözés

$\square$ erkölcsi romlás

elterjedése

$\square$ kilátástalan, bizonytalan jövő

$\square$ fiatalok ált.rossz helyzete

szülöktöl való függés

$\square$ közlekedési nehézségek

$\square$ korrupció

$\square$ lakásproblémák

$\square$ közösség hiánya

$\square$ mnélküliség, elhelyezk. nehézség

$\square$ rossz családi körülmények

$\square$ egyéb

$\square$ létbizonytalanság

$\square$ önálló egzisztencia, család

$\square$ szórakozási és ismerkedési lehetöségek hiánya

Mennyire elégedett Ön a következő dolgokkal?

( $1=$ egyáltalán nem elégedett; ;...5=teljes mértékben elégedett)

6.23 partnerkapcsolataival

6.24 baráti kapcsolataival

6.25 munkavállalási lehetőségeivel

6.26 jelenlegi életszínvonalával

6.27 anyagi helyzetével

6.28 tanulás lehetóségeivel

6.29 azzal az ismeretmennyiséggel, amit idáig szerzett

6.30 személyes élettervei megvalósításának esélyeivel

6.31 jövöbeli kilátásaival

6.32 mindent egybevetve azzal, ahogyan most él?

!KÉRDEZŌ: ADD ODA A 2.SZ. VÁLASZLAPOT!!

6.33 Véleménye szerint az alábbiak közül mi szükséges elsősorban ahhoz, hogy az ember érvényesülhessen Mo-on?
$\square$ akaraterö
$\square$ egészség
$\square$ jó modor
könyöklés, pofátlanság
$\square$ becsület, erkölcs
$\square$ jó családi háttér
nyelvtudás
$\square$ pénz, anyagiak
szerencse
vállalkozó szellem
$\square$ rátermettség

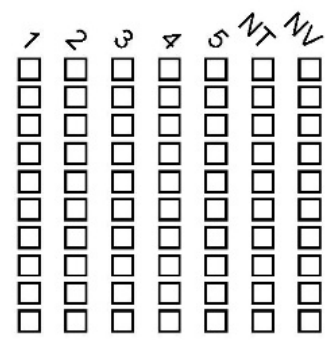

6.34 Véleménye szerint az alábbiak közül mi szükséges másodsorban ahhoz, hogy az ember érvényesülhessen Mo-on?
$\square$ akaraterő
egészség
jó modor
könyöklés, pofátlanság
$\square$ becsület, erkölcs
$\square$ erószak
$\square$ jó családi háttér
$\square$ nyelvtudás
$\square$ pénz, anyagiak
$\square$ szerencse
$\square$ vállalkozó szellem

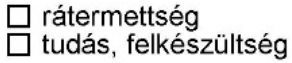

biztos munkahely

jó diploma

kemény munka, szorgalom

összeköttetés, jó kapcsolatok, ismeretség

számítógèpes ismeret

ügyeskedés $\square$ biztos munkahely

jó diploma

kemény munka, szorgalom

összeköttetés, jó kapcsolatok, ismeretség

számítógépes ismeret

$\square$ ügyeskedés 
$\Gamma$

\begin{tabular}{|c|c|c|}
\hline EvaSys & Nyíregyháza ifjúsága 2015 & 일ectric Paper \\
\hline \hline Debreceni Egyetem & A KÉRDÖÍV BIZALMASAN KEZELENDÖ! \\
Egészségügyi Kar & A VÁLASZADÁS ÖNKĖNTES! & \\
& CSAK 19-29 ÉVESEKTÖL KÉRDEZHETÖ! & IP \\
\hline
\end{tabular}

Válasz megjelölése: $\square \bigotimes \square \square \square$ Kérem, használjon tollat vagy vékony hegyủ filcet. Az ürlap automatikus feldolgozásra kerül.

Javitás: $\quad \square \square \square \bigotimes \square$ Az optimális beolvasási eredmények érdekében kérem, kövesse a bemutatott példákat.

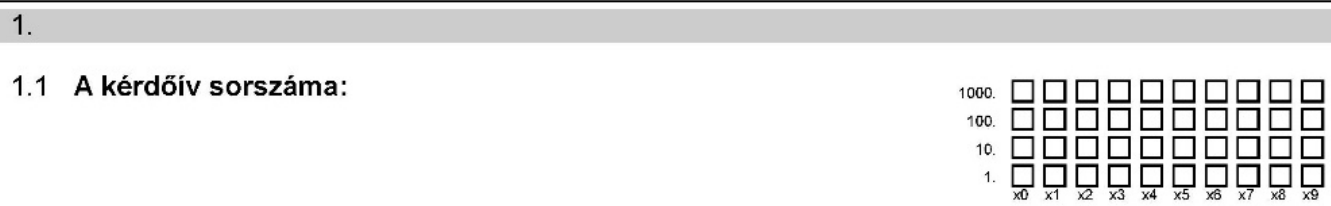

\section{MÉDIA}

Mennyire fontos az Ön számára a ..., mint információforrás?

( $1=$ egyáltalán nem fontos;....5=teljes mértékben)

2.1 televízió?

2.2 a könyvek?

2.3 az internet?

2.4 a rádió?

2.5 az újságok?

2.6 a helyi klubok, társ-i szervezetek, vallási

közösségek?

2.7 a barátai, a családja?

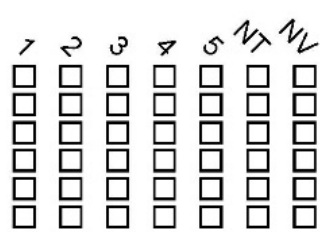

Mennyire tartja megbizhatónak az Ön számára az adott információforrást? (1=egyáltalán nem megbizható,....5=teljes mértékben)

2.8 televízió?

2.9 a könyvek?

2.10 az internet?

2.11 a rádió?

2.12 az újságok?

2.13 a helyi klubok, társ-i szervezetek, vallási közösségek?

2.14 a barátai, a családja?

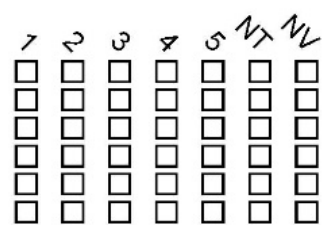

Van-e otthon (ebben a háztartásban, ahol lakik)...?

2.15 vezetékes telefon (elöfizetés)

2.16 számítógép (laptop, tablet)

2.17 internet hozzáférés (elófizetés)

2.18 DVD lejátszó (a számítógépben lévő nem számít)

2.19 házimozi rendszer (szett)

2.20 plazma tévé, LCD TV, LED TV (bármelyik ezek közül)

$\square \square \square \square \square \square \square$

\section{Van-e Önnek saját...?}

2.21 okostelefonja

2.22 mobiltelefonja (csak akkor jelölje, ha nincs okostelefonja)

2.23 mobiltelefonján, okostelefonján internet hozzáférés (bármelyiken a kettö közül)

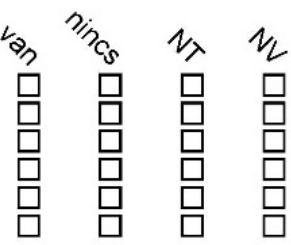

2.24 számítógépe, laptopja (bármelyik a kettö közül) 2.25 tabletie

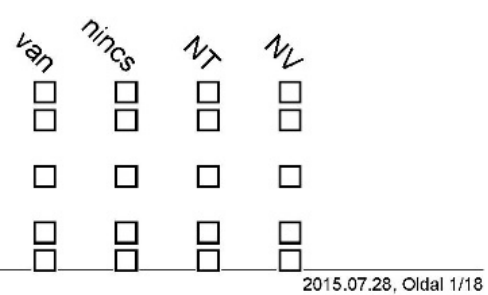




\section{EvaSys \\ 2. MÉDIA}

2.26 e-book olvasója

2.27 digitális fényképezőgép, digitális kamera (bármelyik a kettö közül)

2.28 hordozható $\mathrm{mp} 3 / \mathrm{mp} 4 / \mathrm{mp} 5$ lejátszó (bármelyik ezek közül)

2.29 játékkonzol, pl. Xbox, PS2, PS3, Nintendo Wii (bármelyik ezek közül)

2.30 bankszámlája

2.31 Használ-e Ön számítógépet/laptopot/ tablet-et?

Egy átlagos hétköznap mennyi időt (hány órát és hány percet) tölt Ön ...?

2.32 könyvolvasással (akár hagyományos, akár elektornikus, pl. ebook) (...PERC)

2.33 könyvolvasással (akár hagyományos, akár elektornikus, pl. e-book)

$\square$ NT/NV

2.34 újságolvasással (akár hagyományos, akár elektronikus) (...PERC)

2.35 újságolvasással (akár hagyományos, akár $\square$ NT/NV elektronikus)

2.36 televízió-nézéssel (televízió-műsor, akár hagyományos módon, akár elektronikusa pl. interneten) (...PERC)

2.37 televízió-nézéssel (televízió-müsor, akár hagyományos módon, akár elektronikusa

$\square \mathrm{NT} / \mathrm{NV}$ pl. interneten)

2.38 DVD-zéssel, film, vagy más videó nézéssel (...PERC)

2.39 DVD-zéssel, film, vagy más videó nézéssel

$\square \mathrm{NT} / \mathrm{NV}$

2.40 internetezéssel (...PERC)

2.41 internetezéssel

$\square \mathrm{NT} / \mathrm{NV}$

2.42 rádió hallgatással (akár hagyományos, akár online) (...PERC)

2.43 rádió hallgatással (akár hagyományos, akár online)

$\square \mathrm{NT} / \mathrm{NV}$

2.44 zenehallgatással (akár hagyományos, akár online) (...PERC)

2.45 zenehallgatással (akár hagyományos, akár

$\square \mathrm{NT} / \mathrm{NV}$ online) $\square \quad \square \quad \square \quad \square$

$\square \quad \square \quad \square \quad \square$

$\square \quad \square \quad \square \quad \square$

$\square \quad \square \quad \square \quad \square$ 
EvaSys $\quad$

Nyíregyháza ifjúsága 2015

2. MÉDIA [Folytatás]

Egy átlagos hétvégén mennyi időt (hány órát és hány percet) tölt Ön ...?

2.46 könyvolvasással (akár hagyományos, akár elektornikus, pl. ebook) (...PERC)

2.47 könyvolvasással (akár hagyományos, akár $\square$ NT/NV elektornikus, pl. e-book)

2.48 újságolvasással (akár hagyományos, akár elektronikus) (...PERC)

2.49 újságolvasással (akár hagyományos, akár $\quad \square$ NT/NV elektronikus)

2.50 televízió-nézéssel (televízió-müsor, akár hagyományos módon, akár elektronikusa pl. interneten) (...PERC)

2.51 televízió-nézéssel (televízió-müsor, akár hagyományos módon, akár elektronikusa pl. interneten)

2.52 DVD-zéssel, film, vagy más videó nézéssel (..PERC)

2.53 DVD-zéssel, film, vagy más videó

NT/NV

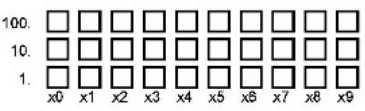

10. $\square \square \square \square \square \square \square \square \square \square \square \square \square \square \square \square$

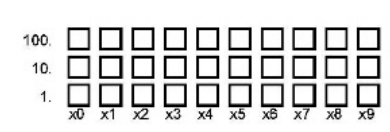
nézéssel

2.54 internetezéssel (...PERC)

2.55 internetezéssel

$\square$ NT/NV

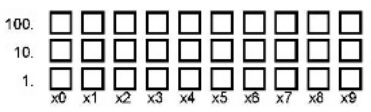

$\square \mathrm{NT} / \mathrm{NV}$

10. $\square \square \square \square \square \square \square \square \square \square$

2.56 rádió hallgatással (akár hagyományos, akár online) (...PERC)

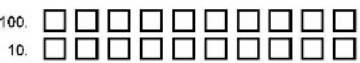

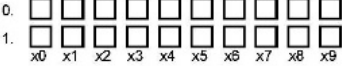

2.57 rádió hallgatással (akár hagyományos,

$\square$ NT/NV

akár online)

2.58 zenehallgatással (akár hagyományos, akár online) (...PERC)

2.59 zenehallgatással (akár hagyományos, akár online)

\section{$\square$ NT/NV}

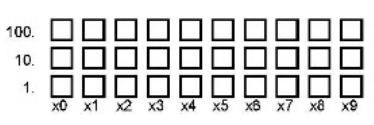

A következőkben a tévézéséhez, internetezéséhez, stb. esetlegesen társuló egyéb tevékenységeiről szeretném kérdezni.

Miközben Ön ... az idő mekkora részében végez Ön más tevékenységet is? (a tevékenység jellege nem számit, lehet média, de egyéb is)

(1=az idó nagy részében; $2=a z$ idó felében; $3=a z$ idö kis részében; 4=soha; $5=$ nem szokott ilyen tevékenységet végezni)
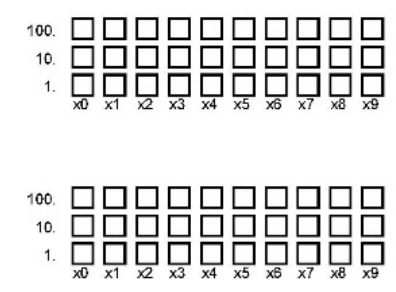

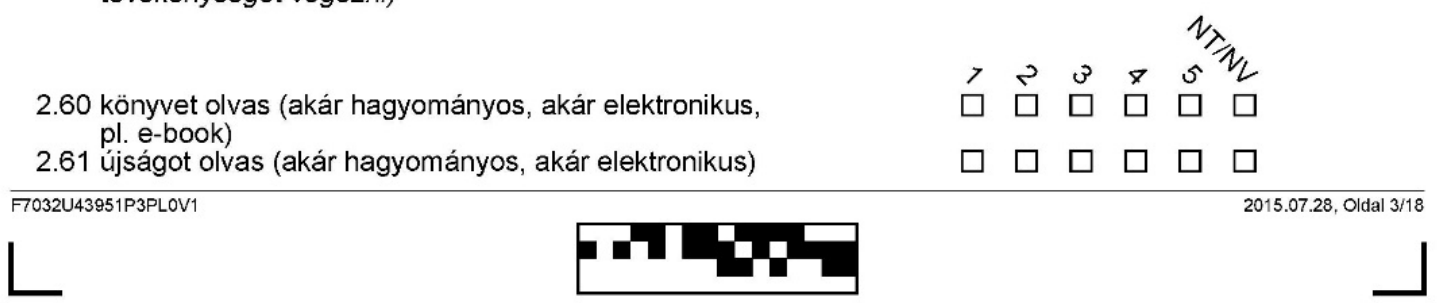


\begin{tabular}{l|l} 
EvaSys & \\
2. MÉDIA [Folytatás]
\end{tabular}

Nyíregyháza ifjúsága 2015

2.62 televíziót néz (tv-müsor, akár hagyományos módon, akár elektronikusa pl. interneten)

2.63 DVD-t, filmet, vagy más videót néz

2.64 internetezik

2.65 rádiót hallgat (akár hagyományos, akár online)

2.66 zenét hallgat (akár hagyományos, akár online)

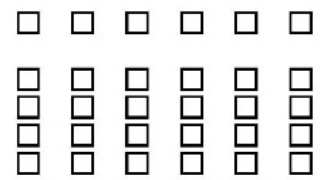

Miközben Ön a SZÁMíTÓGÉPEN/INTERNETEN/MOBILTELEFONON/TABLETEN ... az idõ mekkora részében végez Ön más tevékenységet is. (1=az idő nagy részében; 2=az idő felében; $3=a z$ idó kis részében; 4=soha; 5= nem szokott ilyen tevékenységet végezni)

2.67 online rádiót/zenét hallgat

2.68 játszik

2.69 online tv, vagy más videó tartalmakat néz $8 \mathrm{pl}$. YouTube, stb.)

2.70 keres, böngészik

2.71 cseveg barátaival, ismerőseivel (pl. MSN, Skype, GTalk, Facebook, stb.)

2.72 e-mailt ír/olvas

2.73 közösségi oldalakat használ (pl. Facebook)

2.74 híreket, egyéb szöveges tartalmakat olvas

2.75 dolgozik

2.76 tanul

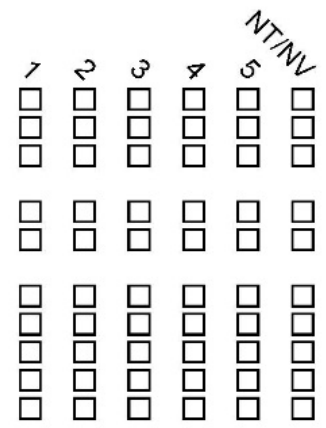

2.77 Tagja-e Ön valamilyen internetes közösség portálnak, például a Facebook-nak, vagy más interneten szerveződő csoportnak?
$\square$ nem (UGRÁS:2.82-2.90)
$\square \mathrm{NT}$

$\square$ igen

2.78 Hány ismerőse van az Ön által leggyakrabban használt közösség oldalon?

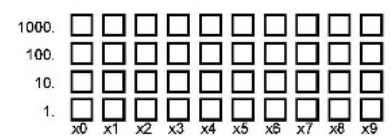

2.79 Hány ismerőse van az Ön által leggyakrabban használt közösség oldalon? $\square$ NT $\square$ NV

2.80 Ebből hány emberrel kommunikál rendszeresen akár személyesen, akár interneten, vagy telefonon?

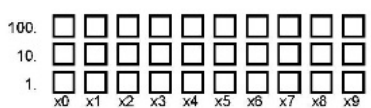

2.81 Ebböl hány emberrel kommunikál rendszeresen akár személyesen, akár interneten, vagy telefonon?

$\square$ NT

$\square \mathrm{NV}$

Milyen gyakran szokott Ön az interneten...?

(1=legalább naponta egyszer; $2=$ hetente többször; $3=$ hetente egyszer; $4=$ havonta többször; $5=$ havonta egyszer, vagy ritkábban; 6=soha;)

2.82 rádiót/zenét hallgatni

2.83 videót,tévét nézni

2.84 játszani

2.85 e-mail-t írni/olvasni

2.86 böngészni/keresni

2.87 chatelni/csevegni

2.88 közösségi oldalakat használni

2.89 híreket olvasni

2.90 dolgozni/tanulni

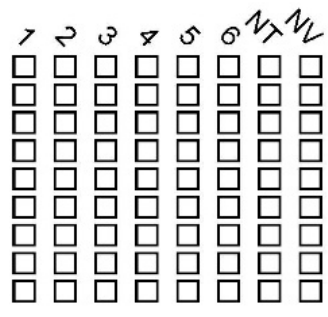

7032U43951P4PLOV1 
EvaSys

Nyíregyháza ifjúsága 2015

2. MÉDIA [Folytatás]

Milyen gyakran szokott Ön ...?

(1=legalabb naponta egyszer; $2=$ hetente többször; 3=hetente egyszer; 4=havonta többször; 5=havonta egyszer, vagy ritkábban;)

2.91 saját magáról hírt, információt (pl. mit csinál éppen, hol volt a hétvégén, stb.), megosztani a közösségi oldalakon?

2.92 mások által közölt magánjellegű információkhoz (pl. családi képek, stb.) hozzászólni?

2.93 közéleti (politikai) kérdésekben hírt/véleményt megosztani/ vitát kezdeményezni?

2.94 közéleti (politikai) kérdésekkel kapcsolatos hírhez/ véleményhez hozzászólni?

2.95 érdekes (nem politikai) híreket, eseményeket megosztani?

2.96 érdekes (nem politikai) hírekhez, eseményekhez hozzászólni?

2.97 cégek, szervezetek közösségi oldalakon történö tevékenységét követni?

2.98 cégekkel, márkákkal kapcsolatosan megnyilvánulni (hozzászólni bejegyzésekhez, lájkolni, stb. ?

\author{
$\operatorname{sos} 800 v^{\prime} v^{2}$

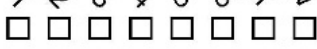 \\ ㅁㅁㅁㅁ \\ ㅁㅁㅁㅁ \\ ㅁㅁㅁㅁ \\ ㅁㅁㅁㅁ \\ ㅁㅁㅁㅁ \\ ㅁㅁㅁㅁ \\ ロ $\square$ ㅁㅁ
}

És milyen gyakran szokta Ön a közösségi oldalakat ... használni?

(1=legalább naponta egyszer; $2=$ hetente többször; $3=$ hetente egyszer; $4=$ havonta többször; $5=$ havonta egyszer, vagy ritkábban; $6=$ soha;)

2.99 a családjával való kapcsolattartásra

2.100régi barátokkal/ismerősökkel való kapcsolattartásra

2.101 szórakozásra

2.102játékra

2.103új barátságok kialakítására

2.104segítségkérésre, tanácskérésére

2.105üzleti kapcsolattartásra

2.106munkakeresésre

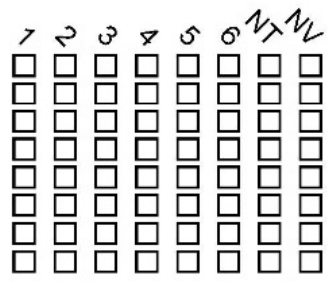

Most beszéljünk azokról a módokról, ahogy az emberek kapcsolatba lépnek, kommunikálnak egymással az internet, illetve mobiltelefon segítségével. Kérem, mondja meg, hogy milyen gyakran használja Ön a következőket?

( $1=$ legalább naponta egyszer; $2=$ hetente többször; $3=$ hetente egyszer; $4=$ havonta többször; $5=$ havonta egyszer, vagy ritkábban; 6=soha;)

2.107Csetelés, azonnali üzenetküldövel pl. MSN-nel,

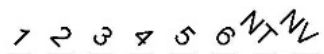
Skype-pal, stb.)

2.108Fórumokban, blogokon hozzászólás

2.109Telefonhívások fogadása és kezdeményezése az interneten keresztül.

2.110Blog-írás.

2.111SMS-küldés.

2.112Hány hagyományos könyv van az Önök háztartásában? (db)

2.113Hány hagyományos könyv van az Önök $\square$ NT

$\square \square \square \square \square \square \square \square$

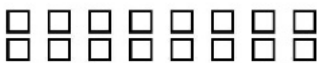

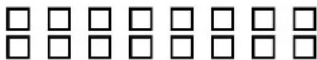
háztartásában? (db)

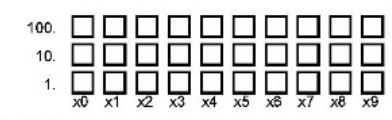

$\square N V$ 
EvaSys

Nyíregyháza ifjúsága 2015

2. MÉDIA [Folytatás]

2.114Hány elektronikus könyv van az Önök háztartásában? (db)

2.115Hány elektronikus könyv van az Önök háztartásában? (db)

$\square$ NT

只品品品品品

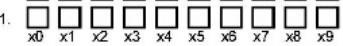

$\square$ NV

\section{SPORT, SZABADIDŐ}

3.1 Végez-e rendszeresen testmozgást, sportol-e (a kötelezō testnevelési órán kívül)? $\square$ igen

$\square$ nem (UGRÁS: 3.14-3.16) $\square$ NT

3.2 Mit sportol Ön rendszeresen?

Miért sportol Ön rendszeresen? NYITOTT KÉRDÉS!

3.3 edzett legyen

3.4 egészséges legyen

3.5 fogyni szeretne

3.6 jó legyen a közérzete

3.7 a jó társaság kedvéért

3.8 szülei javaslatára

3.9 jól nézzen $\mathrm{ki}$

3.10 örömet okoz

3.11 egyéb, éspedig:

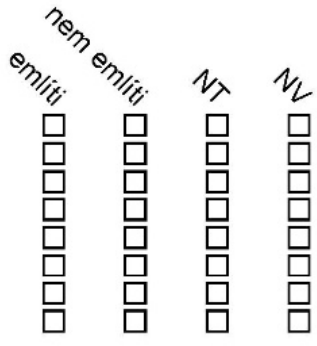

3.12 Általában kivel sportol?

$$
\square \text { egyedül }
$$

$\square$ barátaimmal/ismeröseimmel

családommal

3.13 egyéb, éspedig:

Mennyire elégedett Ön...?

( $1=$ egyáltalán nem elégedett; .... 5=teljes mértékben elégedett)

3.14 az edzettségi szintjével?

3.15 a külsejével?

3.16 az egészségével, közérzetével?

3.17 Összesen hány napot üdült TAVALY (2014-ben) külföldön?

3.18 Összesen hány napot üdült TAVALY

$\square$ NT (2014-ben) külföldön?

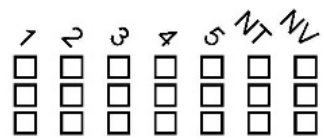

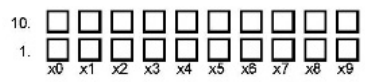

$\square N V$

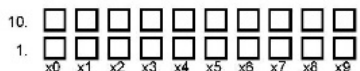

3.19 Összesen hány napot üdült IDÉN (2015-ben) külföldön? 
$\Gamma$

\begin{tabular}{|c|c|c|c|}
\hline EvaSys & Nyíregyháza ifjúsága 2015 & Electric Paper \\
\hline 3. SPORT, SZABADIDŐ [Folytatás] &
\end{tabular}

3.20 Összesen hány napot üdült IDÉN (2015- $\quad \square$ NT $\quad \square$ NV ben) külföldön?

3.21 Összesen hány napot üdült TAVALY (2014-ben) belföldön?

3.22 Összesen hány napot üdült TAVALY

$\square$ NT

(2014-ben) belföldön?

3.23 Összesen hány napot üdült IDÉN (2015-ben) belföldön?

3.24 Összesen hány napot üdült IDÉN (2015- $\quad \square$ NT ben) belföldön?

10. $\frac{\square}{{ }_{x 0}}{ }_{x 1}$

3.25 Meg tudná-e mondani, hogy mennyi szabadideje marad eqy átlagos napon a munka, tanulás, háztartási és ház körüli munkák elvégzése után? (..PERC)

10. $\frac{\square}{{ }_{x 0}} \prod_{x 1}$

$\square N V$

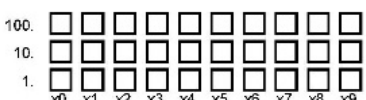

3.26 Meg tudná-e mondani, hogy mennyi szabadideje marad egy átlagos napon a munka, tanulás, háztartási és ház körüli munkák elvégzése után?

$\square$ NT

$\square \mathrm{NV}$

3.27 És mennyi szabadideje marad a hétvégeken, amelyet tetszése szerint pihenéssel vagy szórakozással tölthet? (.. PERC)

3.28 És mennyi szabadideje marad a hétvégeken, amelyet tetszése szerint pihenéssel vagy szórakozással tölthet?

$\square$ NT

$\square \mathrm{NV}$

!!KÉRDEZŌ: CSAK AZOKTÓĹ KÉRDEZNI, AKIK AZ ELŐZŐ KÉT KÉRDÉSRE NEM "0"-ÁT MONDTAKI! NYITOTT KÉRDÉS

$3.29 \mathrm{Hol}$ tölti szabadidejét a leggyakrabban eqv átlagos hétköznapon? A két legfontosabbat említse!
$\square$ otthon
$\square$ utcán
$\square$ kocsmában
$\square$ moziban
$\square$ NT

$\square$ barátoknál

$\square$ bevásárlóközpontban

valamilyen kulturális intézményben (mozi, színház stb.)

$\square$ kint, a szabadban

természetben van

$\square \mathrm{NV}$

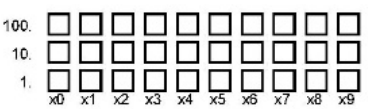

3.30 egyéb helyen, éspedig:

$3.31 \mathrm{Hol}$ tölti szabadidejét a leggyakrabban egy átlagos hétvégén? A két legfontosabbat említse!

$\square$ otthon

$\square$ utcán

$\square$ kocsmában

$\square$ moziban

$\square$ NT

3.32 egyéb helyen, éspedig:

$\square$ barátoknál

$\square$ bevásárlóközpontban

$\checkmark$ valamilyen kulturális intézményben (mozi, színház stb.)

$\square$ kint, a szabadban természetben van

$\square \mathrm{NV}$ $\square$ rokonokná

klubban, múvelődési házban

$\square$ sportpályán

$\square$ egyéb helyen

gyéb helyen, espedig:

$\square$ rokonoknál

klubban, müvelödési házban

sportpályán

$\square$ egyéb helyen 


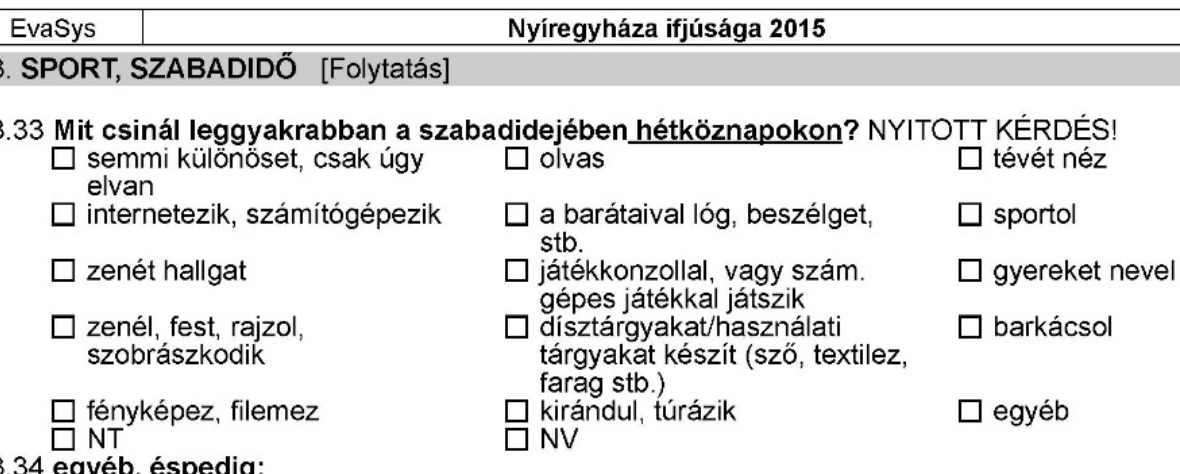

3.35 Mit csinál leggyakrabban a szabadidejében hétvégeken? NYITOTT KÉRDÉS!

$\square$ semmi különöset, csak úgy

$\square$ olvas

$\square$ tévét néz elvan

$\square$ internetezik, számítógépezik

$\square$ zenét hallgat

$\square$ zenél, fest, rajzol, szobrászkodik

$\square$ a barátaival lóg, beszélget,

$\square$ sportol

$\square$ játékkonzollal, vagy szám.

$\square$ gyereket nevel gépes játékkal játszik

$\square$ dísztárgyakat/használati

gyereket neve

$\square$ fényképez, filemez tárgyakat készít (szó, textilez,

farag stb.)

3.36 egyéb, éspedig:

$\square \mathrm{NV}$

Milyen gyakran jár Ön a következō helyekre?

(1:naponta többször; 2 :hetente többször; 3 :hetente egyszer; 4:havonta többször; 5 :havonta egyszer; 6:2-3 havonta; 7:évente többször; 8:egyszer vagy ritkábban; 9:szinte soha;)

3.37 színházba

3.38 art moziba/müvészfilmeket nézni moziba

3.39 más moziba vagy multiplexbe

3.40 könyvtárba

3.41 komolyzenei hangversenyre

3.42 könnyüzenei koncertre

3.43 könyvesboltba

3.44 kiállitásra, múzeumba

3.45 operába

3.46 kávéházba, teázóba, presszóba

3.47 sörözőbe, borozóba, kocsmába

3.48 étterembe

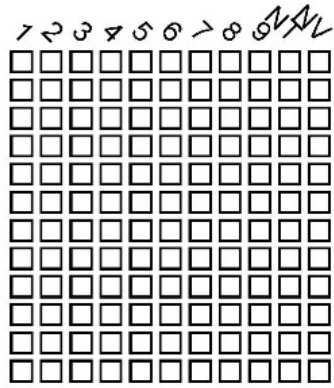

3.49 Általában kivel/kikkel szokott ezekre a helyekre menni? (Több választ is megjelö/het!)
$\square$ családdal/rokonnal
$\square$ barátokkal
$\square$ munkatársakkal
$\square$ egyedül
$\square$ egyéb osztálytársakkal

3.50 egyéb, éspedig: 


\begin{tabular}{|c|c|c|}
\hline EvaSys & Nyíregyháza ifjúsága 2015 & Electric Paper \\
\hline 3. SPORT, SZABADIDŐ [Folytatás] &
\end{tabular}

3.51 Van-e olyan baráti köre, társasága, amellyel gyakran van együtt szabadidejében?
$\square$ van
$\square$ nincs
$\square$ NT

3.52 Van-e olyan törzshelye, állandó találkozóhelye, ahol barátai, ismerősei egy részét valószínűleg akkor is megtalálhatja, ha találkozásukat elöre nem beszélik meg?

$\square$ igen, több ilyen törzshelye is $\square$ igen, egy ilyen törzshelye van

van

$\square N V$

$\square$ nincs törzshelye (UGRÁS a

$\square$ NT köv.kérdésblokkra)

3.53 Felsorolok néhány leírást. Kérem, válassza ki, hogy ezek közül melyik illik legjobban az elöbb jellemzett törzshelyre.

$\square$ szabadtéren van, pl.: utca, tér, $\square$ ez védett, fedett közterületi közterületi sportpálya, park, hely, pl. aluljáró, házak közötti vízpart, stb. átjáró, stb.

$\square$ ez valamilyen múvelödési ház, ifjúsági ház, ahol egyes programokra belépödijat kell

bevásárlóközpont, Plaza, stb.

fizetni, más alkalmakon

szabadon látogatható része,

viszont fizetség nélkül is

nem játékterem vagy

vendéglátóhely, ahol a

látogathatóak

szolgaltatasert vagy a

fogyasztásért fizetni kell

$\square$ ez egyéb hely, az eddigi jellemzések egyike sem illik rá

$\square$ ez valamilyen vendéglátóhely (presszó, étterem, stb.), ahol a fogyasztásért fizetni kell

$\square$ ez valamilyen játékterem biliárdszalon, diszkó, stb., ahol a szolgáltatásért fizetni kell

$\square$ NT

\section{RIZIKÓMAGATARTÁS}

!!KÉRDEZŌ: MOST ADD ÁT A KÉRDŌíYET A MEGKÉRDEZETTNEK ÉS KÉRD MEG, HOGY VÁLASZOLJON A KÖVETKEZŐ KÉRDÉSEKRE!!

4.1 Hány centiméter magas Ön? (cm)

4.2 Hány centiméter magas Ön?

$\square$ NT

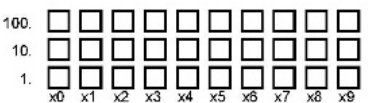

4.3 Hány kiló most az Ön testsúlya? (kg)

$\square \mathrm{NV}$

4.4 Hány kiló most az Ön testsúlya? (kg)

$\square$ NT

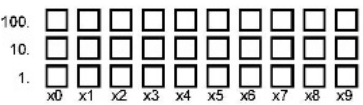

4.5 Akadályozza-e Önt mindennapi tevékenységében bármilyen módon valamilyen tartós betegség, rokkantság, fogyatékosság vagy egyéb lelki probléma?
$\square$ egyáltalán nem
bizonyos mértékig
igen
$\square$ nem tudom, nem emlékszem $\quad$ nem válaszolok

4.6 A barátai, ismerösei között van-e olyan, aki használt már valamilyen kábítószert?
$\square$ igen, több ilyen ismerösöm is
igen, van egy ilyen
$\square$ nem, nincs ilyen ismerösöm
van
$\square$ nem tudom, nem emlékszem
$\square$ nem válaszolok

Kipróbálta-e, használta-e Ön valaha az életében a következő szereket?

4.7 altató, nyugtató orvosi javallat nélkül

4.8 marihuána, hasis (fú, spangli)

4.9 LSD, gomba, meszkalin, más hallucinogének

4.10 amfetamin, metamfetain

4.11 ecstasy

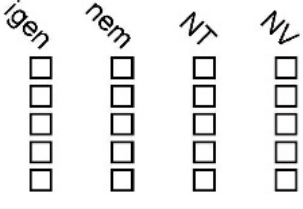

F7032U43951P9PLOV 


\begin{tabular}{|c|c|c|c|c|}
\hline \multirow{2}{*}{\multicolumn{5}{|c|}{\begin{tabular}{l|l} 
EvaSys & \\
RIZIKÓMAGATARTÁS [Folytatás]
\end{tabular}}} \\
\hline & & & & \\
\hline $\begin{array}{l}12 \text { koka } \\
13 \text { crac } \\
14 \text { mák } \\
15 \text { mor } \\
16 \text { szer } \\
17 \text { dop } \\
18 \text { alko } \\
19 \text { fecs } \\
20 \text { új "d }\end{array}$ & $\begin{array}{l}\square \\
\square \\
\square \\
\square \\
\square \\
\square \\
\square \\
\square\end{array}$ & $\begin{array}{l}\square \\
\square \\
\square \\
\square \\
\square \\
\square \\
\square \\
\square \\
\square\end{array}$ & $\begin{array}{l}\square \\
\square \\
\square \\
\square \\
\square \\
\square \\
\square \\
\square \\
\square\end{array}$ & $\begin{array}{l}\square \\
\square \\
\square \\
\square \\
\square \\
\square \\
\square \\
\square\end{array}$ \\
\hline
\end{tabular}

4.21 más szer, éspedig:

4.22 Hány éves volt, amikor először kipróbált bármely kábító hatású szert?

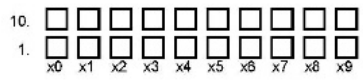

Előfordult-e az elmúlt egy évben, hogy használta ezt a szert? Ha igen, milyen gyakran? (1:gyakran; 2:néhányszor; 3:egyszer; 4:nem használtam;)

4.23 altató, nyugtató orvosi javallat nélkül

4.24 marihuána, hasis (fü, spangli)

4.25 LSD, gomba, meszkalin, más hallucinogének

4.26 amfetamin, metamfetain

4.27 ecstasy

4.28 kokain

4.29 máktea

4.30 morfium, heroin

4.31 szerves oldószer (szipuzás)

4.32 doppingszerek, szteroidok

4.33 alkohol gyógyszerrel

4.34 fecskendóvel bevitt drog

4.35 új "designer" drogok

4.36 más szer, éspedig:

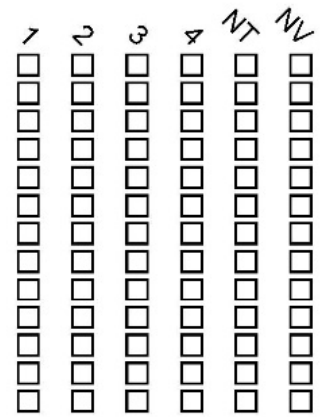

$$
\text { más szer, éspedig: }
$$

Milyen gyakran fordult elö az elmúlt egy évben, hogy:

(1:szinte mindennap; 2:hetente 1-2-szer (hétvégenként); 3:havonta néhányszor; 4:egy-két havonta; 5: ennél ritkábban; 6:egyszer sem;)

4.37 alkoholt fogyasztott

4.38 sört fogyasztott

4.39 bort fogyasztott

4.40 töményitalt fogyasztott

4.41 egy alkalommal megivott $5 \mathrm{v}$. több italt ( 1 ital=korsó sör (5dl) vagy két deci bor v. fél dl tömény)

4.42 ittas volt, berúgott

4.43 pénznyereményért vmilyen szerencsejátékot játszott (pl.lottó,TippMix,online fogadás, póker,kaparós sorsjegy)

4.44 Hány éves volt Ön, amikor először ittas állapotba került?

4.45 Hány éves volt Ön, amikor először ittas állapotba került? $\square$ még sohasem voltam ittas

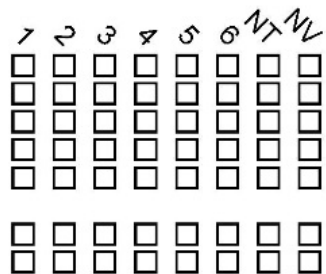

10. 믐무의

$\square$ nem válaszolok 


\begin{tabular}{|c|c|c|}
\hline EvaSys & Nyíregyháza ifjúsága 2015 & ?e Electric Paper \\
\hline \multicolumn{3}{|c|}{ 4. RIZIKÓMAGATARTÁS [Folytatás] } \\
\hline \multicolumn{2}{|c|}{ 4.46 Szokott-e Ön akárcsak alkalmanként dohányozni? } & \multirow{2}{*}{$\begin{array}{l}\square \text { igen, hetente egyszer } \\
\text { (hétvégén) } \\
\square \text { régebben dohányoztam, de } \\
\text { már leszoktam }\end{array}$} \\
\hline$\square$ ig & $\square$ nem, soha (UGRÁS:4.48-ra) & \\
\hline $\begin{array}{l}4.47 \text { Mire gyújtott rá először? } \\
\square \text { cigarettára } \\
\square \text { pipára }\end{array}$ & $\begin{array}{l}\square \text { sodort cigarettára } \\
\square \text { vízipipára }\end{array}$ & $\begin{array}{l}\square \text { szivarra } \\
\square \text { nem emlékszem }\end{array}$ \\
\hline
\end{tabular}

Előfordult-e, megélte-e Ön 14 éves koráig a következőket?

4.48 meghalt az édesapja, vagy az édesanyja

4.49 elváltak szülei

4.50 rendszeresen lerészegedett a szülője vagy a nevelöszülöje

4.51 elvesztette a munkahelyét a szülöje vagy a nevelöszülője

4.52 súlyos anyagi veszteség érte a családjukat

4.53 durva veszekedések voltak a szülei között

4.54 rendszeresen megverték, bántalmazták Önt a szülei vagy a nevelöszülei

4.55 abortusz (ön vagy a partnere)

4.56 szakítás

4.57 súlyos betegség (ön vagy a családjának valamelyik tagja)

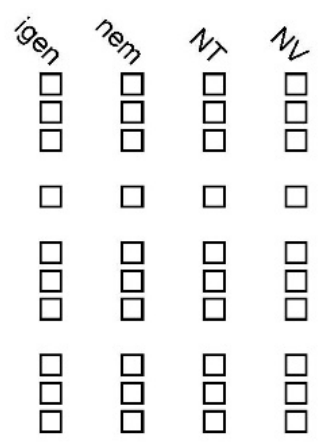

4.58 Az elmúlt 3 évben megfordult-e a fejében az öngyilkosság gondolata?

$\square$ igen válaszolok

$\square$ nem

$\square$ nem tudom

4.59 Volt-e Önnek öngyilkossági kísérlete, és ha igen, hányszor? $\square$ igen, egyszer

$\square$ nem tudom

$\square$ nem válaszolok

$\square$ nem (UGRÁS: 4.62-re)

4.60 Hányszor részesült öngyilkossági kísérlete miatt orvosi kezelésben? (Kérem, irja le, hány alkalommal!)

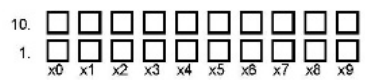

4.61 Hányszor részesült öngyilkossági kísérlete miatt orvosi kezelésben? (Kérem, irja le, hány alkalommal!)

$\square$ nem részesültem egyszer sem $\square$ nem tudom

$\square$ nem válaszolok

4.62 Volt-e már Ön szerelmes?

$\square$ igen, többször is

igen, egyszer

$\square$ nem

4.63 És viszont szerették?

$\square$ igen, mindig

hol igen, hol nem

$\square$ nem

4.64 Hogyan jellemezné Önmagát?

$\square$ szexuálisan kizárólag az

ellenkező nemúekhez

vonzódom

$\square$ nem tudom

$\square$ szexuálisan a saját nememhez és az ellenkező nemúekhez is vonzódom nem válaszolok $\square$ talán, nem vagyok biztos benne

$\square$ talán, nem vagyok biztos benne

$\square$ szexuálisan kizárólag a saját nememhez vonzódom 


\begin{tabular}{|c|c|c|}
\hline EvaSys & Nyíregyháza ifjúsága 2015 & Q Electric \\
\hline \multicolumn{3}{|c|}{ RIZIKÓMAGATARTÁS [Folytatás] } \\
\hline .65 Hán & a szexuális életet? & 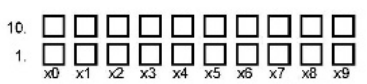 \\
\hline
\end{tabular}

4.67 Ha még nem kezdte el, hány éves korában tervezi elkezdeni?

4.68 Ha még nem kezdte el, hány éves korában tervezi elkezdeni?

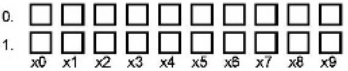
nem kivánok szexuális életet élni, önmegtartóztató életre készülök

4.69 Van-e Önnek jelenleg állandó jellegũ szexuális partnere?

$\square$ igen, házastársam, élettársam $\square$ igen, de nem élünk együtt

$\square$ jelenleg nincs partnerem

4.70 Eddig élete során hány szexuális partnere volt?

4.71 Eddigi élete során hány szexuális partnere volt?

$\square$ nem tudom

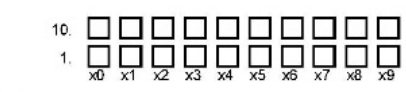

nem

válaszolok

4.72 Milyen gyakran él Ön nemi életet? $\square$ naponta

$\square$ havonta többször

$\square$ hetente többször

ritkábban

$\square$ nem tudom

$\square$ nem válaszolok $\square$ egyéb

$\square$ igen, több is van

hetente

nem élek nemi életet (UGRÁS a köv.blokkra)

4.73 És mi a jellemzőbb Önre?

$\square$ mindig védekezek a nem kívánt terhesség ellen

$\square$ időnként védekezek, időnként nem

nem szoktam védekezni

IKEDVES VÁLASZOLÓ! KÉREM, MOST ADJA VISSZA A KÉRDŐÍVET A KÉRDEZŐBIZTOSNAK ÉS SEGITTSE TOVÁBBI VÁLASZAIVAL A KUTATÁST! KÖSZÖNJÜK! 
EvaSys $\quad$ Nyíregyháza ifjúsága 2015

5. LAKÁSHELYZET, ÉLETKÖRÜLMÉNYEK

5.1 Hányan élnek Önnel együtt egy háztartásban, Önt is beleszámítva?

5.2 Hányan élnek Önnel együtt egy háztartásban, Önt is beleszámítva?

$\square N T$

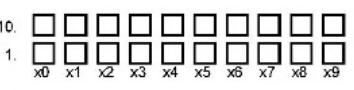

5.3 Ebből hány fő 14 éven aluli?

5.4 Ebből hány fő 14 éven aluli?

$\square$ NT

5.5 És hányan dolgoznak jelenleg? (fö)

5.6 És hányan dolgoznak jelenleg? (fö)

5.7 Kérem, mondja meg, hogy hány testvére van! (Mindenki számít, akit a kérdezett testvérének tart, legyen az vér szerinti, vagy egyéb.)

$\square \mathrm{NV}$

$\square \mathrm{NV}$

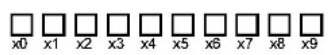

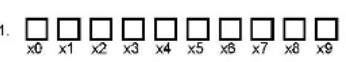

$\square \mathrm{NV}$

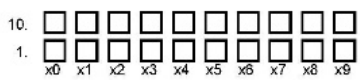

5.8 Kérem, mondja meg, hogy hány testvére van! (Mindenki számít, akit a kérdezett testvérének tart, legyen az vér szerinti, vagy egyéb.)

$\square \mathrm{NT}$

Kikkel él Ön egy háztartásban? NYITOTT KÉRDÉS!
5.9 édesapa
5.10 nevelóapa
5.11 édesanya
5.12 nevelöanya
5.13 férj
5.14 feleség
5.15 élettárs
5.16 gyereke
5.17 testvér
5.18 nagyszülö
5.19 após
5.20 anyós
5.21 Egyéb rokon, éspedig:

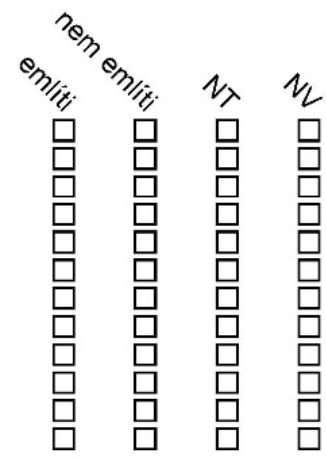

5.22 Egyéb nem rokon, éspedig:

Kik nevelték Önt 14 éves koráig? NYITOTT KÉRDÉS!

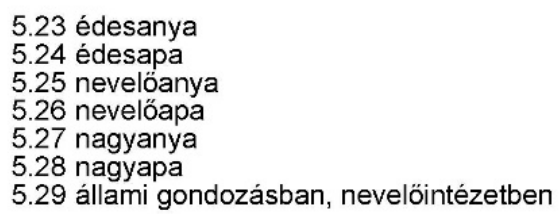

5.26 nevelöapa

5.27 nagyanya

5.28 nagyapa

5.29 állami gondozásban, nevelöintézetben

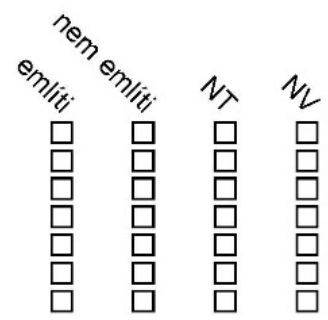


\begin{tabular}{c|c} 
EvaSys & Nyíregyháza ifjúsága 2015 \\
5. LAKÁSHELYZET, ÉLETKÖRÜLMÉNYEK [Folytatás]
\end{tabular}

5.30 egyéb, éspedig:

$5.31 \mathrm{Mi}$ (volt) az édesanyja/nevelőanyja (utolsó) FOGLALKOZÁSA?

$\square$ mg-i fizikai munkás $\square$ segédmunkás (nem mg-i)

$\square$ szakmunkás (nem mg-i)

$\square$ kvetlen termelésirányító ( $p l$. múvezetö)

$\square$ beosztott diplomás
$\square$ alsó vez. (oszt.vez.alatt)

$\square$ felső vezető (oszt.vez.fölött)

$\square$ NT

betanított munkás (nem mg-i)

$\square$ egyéb (dipl.-hoz nem kötött) szellemi

középszintü vez. (oszt.vez.)

NV

$5.32 \mathrm{Mi}$ (volt) az édesanyja/nevelőanyja legmagasabb befejezett iskolai végzettsége?
$\square$ kevesebb, mint 8 osztály
szakközépisk., technikum
felsőfokú szakképzés
$\square 8$ általános
gimnázium
doktori fokozat (PhD/DLA)
$\square$ fóiskola
NT
szakmunkásképző, szakisk
érettségi utáni szakképzés
$\square$ egyetem

$5.33 \mathrm{Mi}$ (volt) az édesapja/nevelőapja (utolsó) FOGLALKOZÁSA?

$\square$ mg-i fizikai munkás $\square$ segédmunkás (nem mg-i)

$\square$ szakmunkás (nem mg-i) $\square$ kvetlen termelésirányító (pl. müvezetö)

$\square$ beosztott diplomás
$\square$ alsó vez. (oszt.vez.alatt)

$\square$ felsö vezetö (oszt.vez.fölött)

NT

$\square$ betanított munkás (nem mg-i)

egyéb (dipl.-hoz nem kötött) szellemi

középszintü vez. (oszt.vez.)

NV

$5.34 \mathrm{Mi}$ (volt) az édesapja/nevelőapja legmagasabb befejezett iskolai végzettsége?
$\square$ kevesebb, mint 8 osztály
szakközépisk., technikum
felsőfokú szakképzés
$\square$ gimnázium
doktori fokozat (PhD/DLA)
fóiskola
NT
szakmunkásképző szakisk
érettségi utáni szakképzés
$\square$ egyetem
NV

5.35 Ön a szüleitől külön kasszán él-e?

$\square$ igen

$\square$ nem

NT

5.36 Milyen gyakran fordult elő az Önök háztartásában (ahol él) az elmúlt 12 hónapban, hogy a hónap végére elfogyott a pénzük:
$\square$ havonta
$\square$ félévente
kéthavonta
$\square$ ennél ritkábban
háromhavonta
NT
NV
$\square$ nem fordult elö

5.37 Abban a háztartásban, ahol él, a napi megélhetésen túl tudnak-e félre tenni pénzt rendszeresen vagy esetenként?
$\square$ rendszeresen
$\square$ esetenként
NT

$\square$ tudnának, de nem akarnak

nem tudnak félretenni

$\square \mathrm{NV}$

5.38 Mennyi az Önök háztartásának átlagos havi nettó

össziövedelme, beleértve az Ón és a háztartás összes

tagjának jövedelmét is?

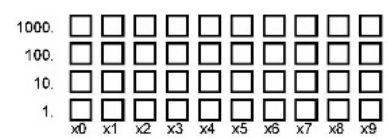

5.39 Mennyi az Önök háztartásának átlagos havi nettó összjövedelme, beleértve az Ön és a háztartás összes tagjának jövedelmét is?

$\square$ NT

$\square$ NV

HA NEM VÁLASZOL A FENTIRE!

5.40 Kérem, sorolja be a háztartása átlagos havi nettó összjövedelmét a megfelelő kategóriába!
30ert vagy kevesebb
91-120eFt között
201-250eFt között
401-500eFt között
701-800eFt között
1 millió fölött

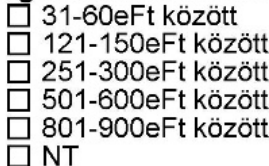

61-90eFt között

151-200eFt között

301-400eFt között

601-700eFt között

901ezer - 1 millió Ft között

NV 
EvaSys $\quad$ Nyíregyháza ifjúsága 2015

5. LAKÁSHELYZET, ÉLETKÖRÜLMÉNYEK [Folytatás]

5.41 Mennyi az Ön átlagos havi nettó jövedelme? (Kérem, a munkabér, ösztöndij, zsebpénz mellett MINDEN jövedelmet vegyen figyelembe.)

5.42 Mennyi az Ön átlagos havi nettó

$\square$ NT

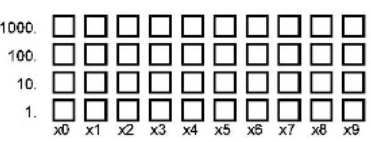

jövedelme? (Kérem, a munkabér,

ösztöndij, zsebpénz mellett MINDEN

jövedelmet vegyen figyelembe.)

5.43 Van-e Önnek, illetve annak a háztartásnak, amelyben Ön él bármilyen adóssága, hitele?

$\square$ van

$\square$ nincs (UGRAS: 5.52-re) $\square$ NT

Milyen hitellel, adóssággal rendelkezik?

5.44 lakáshitelle

5.45 gépjármühitellel

5.46 (szabad felhasználású) személyi kölcsönnel

5.47 folyószámla hitellel

5.48 hitelkártyával

5.49 áruhitellel

5.50 Egyéb, éspedig:

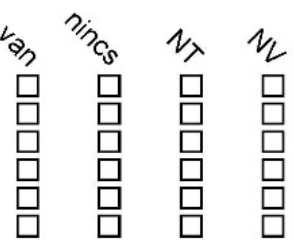

5.51 Okoz-e Önnek problémát a hitel(ek) törlesztése?

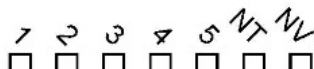
(1=egyáltalán nem okoz problémát ..... 5=teljes mértékben problémát okoz)

5.52 Összességében hogy érzi, Önök anyagilag:

$\square$ gondok nélkül élnek $\square$ beosztással jól kijönnek

$\square$ hónapról-hónapra anyagi $\quad \square$ nélkülözések között élnek gondjaik vannak

$\square$ NV

$\square$ éppen hogy kijönnek a jövedelmükből $\square$ NT

5.53 Kérem, mondja meg, hogy az alábbiak közül Ön melyik csoportba sorolná saját magát?
$\square$ alsó társadalmi csoport
$\square$ alsóközép társadalmi csoport
$\square$ felsó
$\square$ felső társadalmi csoport
$\square$ középsö társadalmi csoport NT

5.54 Az év legnagyobb részében hol lakik Ön?

$\square$ szüleinél lakik

$\square$ házastársánál, élettársánál lakik

$\square$ ismerősöknél lakik

$\square$ albérletben többekkel együtt

egyéb

$\square$ a saját lakásában lakik

házastársa, élettársa szüleinél

lakik

$\square$ teljes lakást bérel magánszemélytöl

kollégista

$\square$ NT

5.55 Amennyiben az előző kérdésnél az "egyéb" opciót választotta, kérem írja le mire gondolt!

\author{
a saját házában lakik \\ rokonoknál lakik \\ $\square$ lakást bérel önkormányzattól \\ $\square$ intézményben él
}

5.56 Melyik településen tölti az év legnagyobb részét? 
\begin{tabular}{l|c|c|}
\hline EvaSys & Nyíregyháza ifjúsága 2015 & Electric Paper \\
\hline
\end{tabular}

5. LAKÁSHELYZET, ÉLETKÖRÜLMÉNYEK [Folytatás]

5.57 És ez az Ön otthona, állandó lakóhelye-e vagy sem? Kérem, ha csak névlegesen van valahova bejelentve, ne azt tekintse az otthonának, az állandó lakóhelyének!

$\square$ állandó lakhelye $\square$ nem az állandó lakhelye $\square$ NT

$\square \mathrm{NV}$

5.58 Állandó lakóhelye szerint hol él Ön?
$\square$ szüleinél
házastársánál, élettársánál
ismerósöknél
$\square$ a saját lakásában
házastársa, élettársa szüleinél
teljes lakást bérel
a saját házában
rokonoknál
magánszemélytől
$\square$ albérletben többekkel együtt
$\square$ kollégista
lakást bérel önkormányzattól
$\square$ egyéb
$\square$ NT
állami gondozott
NV

5.59 Amennyiben az előző kérdésnél az "egyéb" opciót választotta, kérem írja le mire gondolt!

5.60 Megfelelőnek tartja-e jelenlegi lakáskörülményeit?
$\square$ igen
$\square$ nem
$\square$ NT

5.61 Ha együtt él szüleivel: el akar-e onnan költözni a közeljövőben?

$\square$ igen, szeretnék és már $\square$ igen szeretnék, de nem tudok konkrét tervem is van

$\square \mathrm{NV}$

$\square$ NT

5.62 Mindent mérlegelve elköltözne-e Nyíregyházáról?
$\square$ igen
nem
$\square$ szeretne, de nem tud
$\square$ igen, de csak másik
településre
$\square$ NT
$\square \mathrm{NV}$

5.63 Hány szoba van az otthonában? ( $d b$, a 12 négyzetméternél nagyobb lakóhelyiségek száma)

5.64 Hány szoba van az otthonában?

$\square$ NT

$\square \mathrm{NV}$

$\square$ nem szeretnék

5.65 Hány fél szoba van? ( $d b$, a 6 négyzetméternél nagyobb fél

szoba=12 négyzetméternél kisebb lakóhelyiségek száma)

5.66 Hány fél szoba van?

$\square$ NT

$\square$ NV

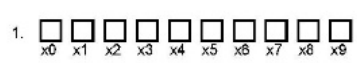

5.67 Hány négyzetméter a lakás alapterülete?

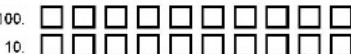

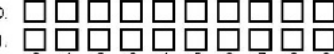

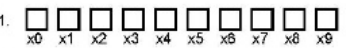

$\square$ talán

igen, de csak külföldre

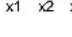

\title{
6. KÖZÖSSÉGI ÉLET
}

6.1 Mióta él Nyíregyházán? (éve)

6.2 Mióta él Nyíregyházán?

$\square$ születése óta

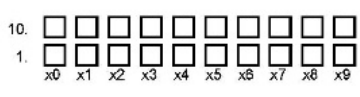


$\Gamma$

Evasys

Nyíregyháza ifjúsága 2015

6. KÖZÖSSÉGI ÉLET [Folytatás]

6.3 Mit szeret az itteni életben? Sorolja fel, ami eszébe jut!

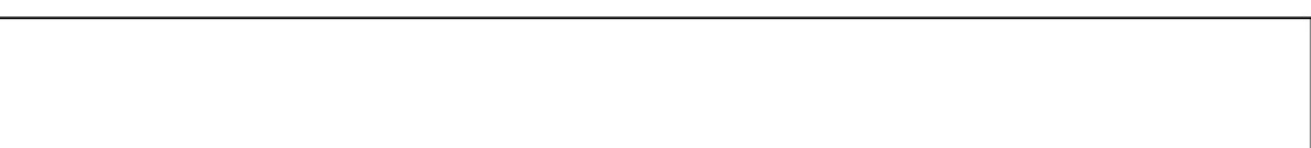

6.4 Mi az, amit nem szeret, ami zavarja az itteni életben?

6.5 Mi az, amin szívesen változtatna?

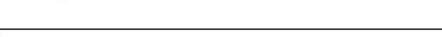

6.6 Részt venne-e egy olyan kutatásban, amely a városban élő fiatalok kapcsolati hálózatát méri fel kapcsolati napló segítségével?

$\square$ igen $\square$ nem

\section{GENERÁCIÓK EGYÜTTMÜKÖDÉSE}

7.1 Milyen gyakran találkozik idősekkel?
$\square$ naponta többször
$\square$ hetente
$\square$ naponta
kéthavonta
$\square$ havonta többször
$\square$ félévente
hetente többször
havonta
soha
$\square$ ritkábban

7.2 Hogyan kommunikálnak leggyakrabban?
$\square$ személyesen
$\square$ telefon
$\square$ egyéb módon
$\square$ interneten

7.3 Milyen tevékenységeket szoktak együtt végezni?

7.4 Milyen tevékenységeket végezne szívesen együtt idősekkel, milyen tevékenységekbe vonná be időskorú ismerōseit? 
EvaSys

Nyíregyháza ifjúsága 2015

(2) Electric Paper

8. KÉRDÉSEK A KÉRDEZÖHÖZ

8.1 Milyen jellegũ épületben van a lakás?

$\square$ családi házban

$\square$ többlakásos villában,

$\square$ régi típusú, városi (bér)házban

$\square$ új típusú városi (bér)házban, új építésű társasházban

sorházban, társasházban

$\square$ panel

$\square$ nem tudja

ellemezd a lakást!

8.3

8.4

8.5

A válaszadó:

8.6 egyedül válaszolt
8.7 a szülei, nevelöszülei is hallották a válaszokat

8.8 a házastárs, élettárs is hallotta a válaszokat

8.9 más személy is hallotta a válaszokat

8.10 más személy is beleszólt a válaszokba

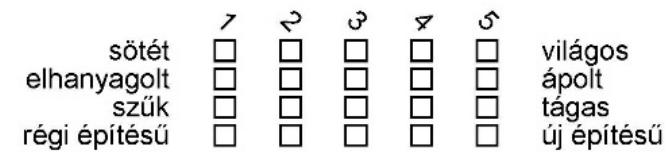

8.11 Kellett-e segíteni a válaszadónak az önkitöltős kérdőív kitöltése során?

$\square$ igen

$\square$ nem

8.12 Hány percig tartott az interjú? (...PERC)

8.13 Körzet neve:
$\square$ Óros
$\square$ Újkistelekiszőló
$\square$ Huszártelep
Jósaváros II.
$\square$ Bokortanyák

$\square$ Örökösföld

Ókistelekiszőlő

$\square$ Kertváros

Hímes

Nyírszölös

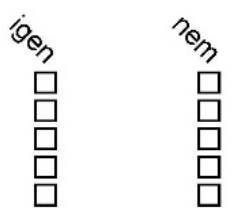

8.14 Egyéb megjegyzés:
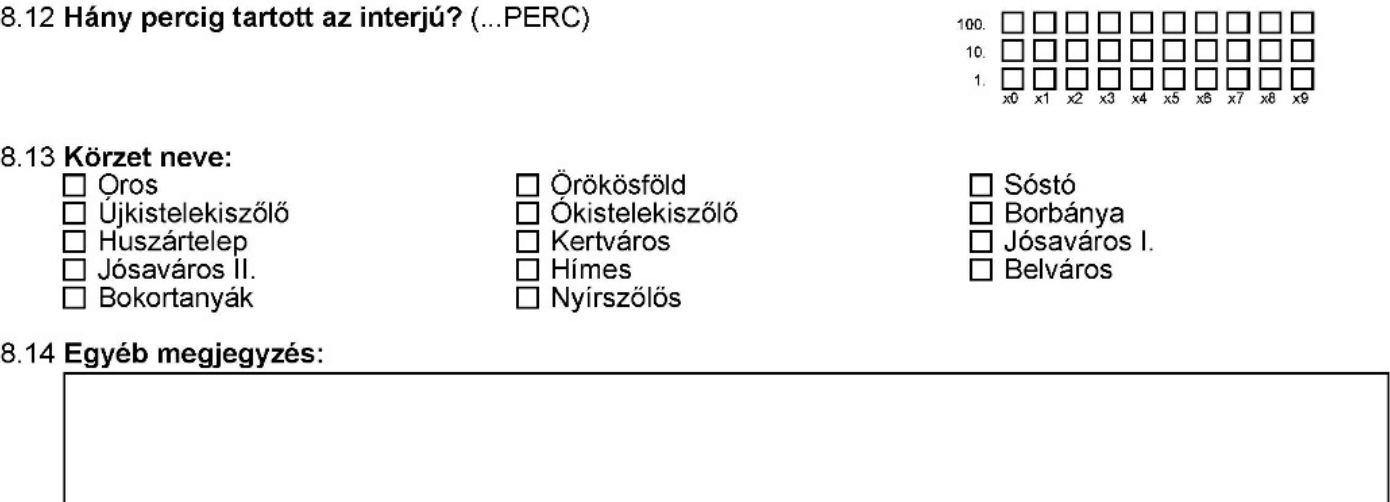

Belváros 